REVISTA DE DERECHO UNED, NÚM. 10, 2012

\title{
CONSIDERACIONES SOBRE LA FORMACIÓN DEL BOTÍN DE GUERRA COMO RES IN PATRIMONIO POPULI: DE LA MONARQUÍA A LA ÉPOCA PROTO-REPUBLICANA ${ }^{1}$.
}

\author{
José Miguel PiQuer Marí \\ Universitat de València Estudi General
}

Resumen: Este estudio tiene por objeto tratar el botín de guerra como patrimonio del Estado; en particular tratamos la formación del botín desde sus inicios durante la época monárquica hasta su configuración como patrimonio del Estado con el advenimiento de la Republica. Por tanto, estudiamos el proceso de formación de una categoría jurídica administrativa consolidada durante la Republica, pero que empezó a conformarse materialmente durante la Monarquía.

Abstract: This study intens to study the booty of war as State property, in particular the formation of the booty from its beginnings during the monarchy to its configuration as assets of the State with the advent of the Republic. Therefore We study the formation of a consolidated administrative legal status in the Republic, but that start to settle materially during the monarchy.

Palabras Clave: Botín de guerra-Monarquía-República-Roma-res in patrimonio populi-populus.

Key words: Booty-Monarchy-Republic-Roma-res in patrimonio populi-populus

1 Este artículo es producto de una comunicación presentada en las Jornadas de derecho Administrativo y Financiero Romano y Actual, celebradas en Valencia en Diciembre del 2011.

(C) UNED. Revista de Derecho UNED, núm. 10, 2012 
Sumario: I. Introducción.-II. Análisis histórico: El régimen jurídico del botín de guerra durante la monarquía: II.1. Los textos legendarios: la sociedad pre-urbana. II.2. La monarquía latino-sabina: gentilidades, proto-urbanismo y guerra privada: a. Testimonios e interpretación. b. Justificación de la interpretación. II.3. La monarquía etrusca: venta del botín; populus, urbanismo: a. Testimonios e interpretación. b. Justificación de la interpretación. II.4. La etapa proto-republicana.-III. Conclusión.

\section{INTRODUCCIÓN}

"Anda y anuncia a los romanos que es voluntad de los dioses celestiales que Roma sea la capital del mundo. Por tanto, que ellos practiquen el arte militar, y que sepan, y que asi lo comuniquen a sus sucesores, que no habrá poder humano capaz de resistir a las armas romanas» (Liv. 1.16.6-8) y es que la ganancia económica era para los romanos, en palabras de $\mathrm{KEAGAN}^{2}$, parafraseando a HARRIS, "parte integral de la guerra y de la expansión de poder».

La guerra, según nos cuenta Livio, forma parte del ADN cultural romano y de la actividad colectiva del pueblo de Eneas; el hecho de que esta actividad tenga el carácter colectivo hace que surja la cuestión del botín como bien susceptible de pertenecer a la comunidad así como su destino. En otras palabras, nos cuestionamos si tales bienes capturados llegaron a considerarse bienes pertenecientes al Estado -res in patrimonio populi- ${ }^{3}$ desde los inicios de Roma o si por el contrario, dicha categoría nació ya en época republicana, como es comúnmente aceptado.

El trabajo que presentamos a continuación tiene una doble finalidad: primera, contribuir a la formación de los conceptos y dogmas propios de la Administración, necesidad de la que entre nosotros se alza como portavoz el prof. Antonio FERNÁNDEZ DE BUJÁN ${ }^{4}$.

2 KEAGAN, J., Historia de la guerra, trad. Francisco Martín Arribas, A History of Warfare, Londres 1993, Barcelona 1995, pág. 323.

${ }^{3}$ Las formas de expresión que utilizaban los romanos para referirse a los bienes patrimoniales del Estado son bastante elocuentes por su expresividad, como son las expresiones res in patrimonio populi (D.41.1.14pr) in patrimonio populi Romani (Flor. Ep. Liv. 2.142), res in pecunia populi (D.18.1.6pr) o in patrimonio fisci (D.18.1.72.1) o patrimonium publicum (Cic. Tusc. 3.20). En todas las expresiones se indican de un modo nítido las notas que caracterizan el concepto de res in patrimonio populi, esto es, cosas o bienes que pertencen al populus romanus.

${ }^{4}$ La obra del autor es amplisima en este campo tanto entre artículos como en trabajos monográficos. Destacamos recientemente: Derecho Administrativo Romano: 
Y, segunda, contribuir a estudiar en particular el inicio del proceso de formación de la categoría jurídica de los bienes patrimoniales del Estado a partir del botín de guerra, por ser éste una de las formas más antiguas por la que los miembros de una sociedad política como tal (populus) tiene para incrementar sus bienes y destinarlos a actividades o fines que les son comunes, por tanto, tienen naturaleza patrimonial Estatal y finalidad económica, tal y como parece que se define por la doctrina romanística ${ }^{5}$.

Instituciones, Conceptos, Principios y Dogmas Revista General de Derecho Romano 16 (2011); Hacia un tratado de Derecho Administrativo Romano, Revista General de Derecho Romano 15 (2010) Perspectivas de estudio en temática de Derecho Administrativo romano, surgidas a tenor del pensamiento y la obra de G.B. Impallomeni en Revista INDEX, Nápoles, 1998, págs. 463-487; Fides publica e instrumenta publice confecta en Derecho romano en Revista de Estudios Latinos, Madrid, 2001, págs. 189200; La administración provincial romana en revista IURA, Nápoles, 2004, La administración de Justicia: órganos jurisdiccionales y judiciales en Revista Latinoamericana de Derecho Romano (Buenos Aires, 2007), págs. 1-12. Hacia un Derecho Administrativo y Fiscal Romano (Director). Ed. Dykinson. Madrid 2011 «Derecho público romano», Ed. Civitas, $13^{\circ}$ ed., Madrid, 1996.

${ }^{5}$ Hemos de tener en cuenta la consideración profunda que hace ORESTANO, R., Il problema delle persone giuridiche in diritto romano, I Torino 1968, pág. 112, quien considera lingüísticamente el término res, cuyo origen referido al populus, etc. resulta imposible de conocer, como punto unificador de naturaleza lingüística que utilizado de un modo unitario y adjetivado sirve para acentuar una dato étnico (res Romana, res Albana) o de un más general la pertenencia a la comunidad en cuanto tal.

De las diversas definiciones de la romanística, seleccionamos las siguientes:

FERNÀNDEZ DE BUJÁN, A., Hacia un tratado de Derecho Adminsitrativo, RGDR, 2010, pág. 32 para quien son aquellas cosas que producen un beneficio económico para el Estado. También en Derecho Administrativo Romano: Conceptos.

SCHERILLO, G., Lezioni di diritto romano-Le cose I. Concetto di cosa-cose extrapatrimonium, Milano 1945, pág. 96 señala que el criterio que distingue las res in patrimonio populi de las cosas de uso común se fundaba en el «impiego» que el pueblo romano hacía de las distintas cosas. De tal forma que aquellas que quedaban sujetas a la gestión económica para obtener los recursos necesarios para cubrir los fines propios de la comunidad política, formaban parte de su patrimonium.

GROSSO, G., Corso di diritto romano. Le cose. Con una nota di lettura di Filippo Gallo en Rivista di diritto romano I (2001), págs. 1-137 en especial pág. 37. Según el romanista italiano, son públicas las cosas tanto las que están destinadas al uso público como aquellas que forman un conjunto de bienes destinados a sostener las cargas del Estado o de la ciudad (res in patrimonio o in pecunia populi romani).

ASTUTI, G., voz Cosa en ED 11 (), págs. 1-19 en especial págs. 4-5 quien las define por un destino a una función pública.

ZOZ, G., Riflessione in tema di res publicae, Torino 1999 apunta que las res publicae en época antigua, hasta el Principado, pertenecerían al pueblo romano si bien distingue dos fases: la primera, hasta la formación de una entidad abstracta, donde los bienes pertenecerían a los habitantes en una especie de copropiedad, y una segunda, donde se configuraría como bienes del pueblo romano entendido como entidad abstracta que ejercitaría un poder unitario sobre el ager publicus. 
Decimos proceso de formación porque, como veremos, el botín de guerra como patrimonio del pueblo romano es aceptado como tal en época republicana, pero creemos que a lo largo de la monarquía se van configurando los elementos que lo formarán posteriormente; a saber, la existencia de un bien común del cual es titular un sujeto público de derecho (el populus) y destinado a satisfacer las necesidades de la sociedad política, especialmente si aceptamos la tesis de SPAGNUOLO VIGORITA-MERCOGLIANO, de que los gastos de comunidad se hiciesen efectivos con el botín de guerra y con las contribuciones impuestas a los enemigos.

Por tanto, la formación política de la sociedad romana como posible titular de un patrimonio ${ }^{6}$, como populus y civitas, y el desarrollo urbanístico y cultual (religioso, militar y civil) como medio en el que se pueden generar gastos a cuya satisfacción pueda contribuir el botín de guerra, son las directrices que nos servirán para analizar la formación y regulación del régimen jurídico durante la época monárquica en sus diferentes fases, desde los tiempos más antiguos, pasando por las monarquías latino-sabinas y etruscas para finalizar en la época proto-republicana.

\section{ANÁLISIS HISTÓRICO DEL RÉGIMEN JURÍDICO DEL BOTÍN DE GUERRA DURANTE LA MONARQUÍA}

\section{II.1. Los textos legendarios}

Iniciamos el estudio de la formación dogmática de la res in patrimonio populi acudiendo fuentes literarias romanas que constituyen la principal fuente de información para este periodo, empezando por los testimonios de carácter legendario o mítico.

Decimos legendarios porque, si bien se trata de fragmentos cuya historicidad es más que dudosa, sin embargo pueden tener un cierto trasfondo de verdad que nos puede permitir percibir hechos o acontecimientos que, con el tiempo, pueden haber contribuido a la formación dogmática de una categoría jurídica.

Se trataría de hechos y acontecimientos que, sin ser totalmente históricos, encierran condiciones sociales, políticas, etc. susceptibles

${ }^{6}$ DH. 3.1.4-5 (quien refiere la existencia de unas tierras públicas, disfrutadas por los reyes hasta Numa y que a partir de Tulio Hostilio dejaron de ser públicas para pasar a ser hereditarias de los monarcas). 
de ser explicables con la ayuda de otras ciencias.Se trataría, en definitiva, de no caer en un hipercriticismo de la tradición histórica, por no saber, como diría MOMIGLIANO, «leer entre líneas» ${ }^{7}$.

Para poder tratar esta cuestión acudimos a Dionisio de Halicarnaso y a Tito Livio ${ }^{8}$, entre otros, como Plutarco ${ }^{9}$ o Macrobio.

De los fragmentos relativos a la época legendaria de la historia de Roma poco podemos extraer; con todo, parece que los textos muestran una sociedad pre-urbana anterior donde el botín de las razias y de los actos de pillaje se distribuye entre los miembros del grupo. Quizás podamos hablar de lo que KRADER ${ }^{10}$ denomina «Sociedades simples sin Estado».

Dionisio de Halicarnaso ${ }^{11} 1.42 .3$ refiriéndose a los compañeros de Hércules (arcadios con Evandro y aborígenes de Fauno), dice que «se apoderaron de los territorios de alrededor, cada grupo para su propio provecho». Al hablar de Hércules dice que a los prisioneros que llevaba consigo durante un tiempo, les entregó tierras y riquezas conseguidas de otros «una vez que le hubiesen ayudado animosamente».

Obsérvese como del texto se deduce que el botín queda distribuido entre los miembros del grupo y que el líder, llamémoslo por ahora así, del grupo tiene facultades de disposición sobre el mismo, pudiendo, por ejemplo, atribuir la libertad a esclavos con bienes que forman parte del botín en función de los intereses del momento.

El segundo fragmento que traemos a colación también sigue una línea similar, a saber, que D. H. 1.57.1 al hablarnos de la fundación y construcción de la ciudad por Eneas, afirma que «haciendo incursiones en los territorios de alrededor, cogía cuanto le era útil para su fundación y de lo que podía resultar más doloroso verse desposeído, como hierro, madera y aperos de labranza».

7 Así mismo, BERNARDI, A., Dagli ausiliari del rex ai magistrati de la respublicaen Athenaeum 30 (1952), págs. 1-58 en especial pág. 4 apunta que el hipercriticismo ha llevado las más de las veces a aplicaciones racionalistas que no parece que se correspondiesen con la realidad.

8 MOMIGLIANO, A., An interim report on the origins of Rome en JRS 53 (1963) págs. 95-121 en especial 96 realiza una breve referencia sobre los historiadores romanos y sus influencias.

9 Plutarco. Vidas Paralelas 2, Trad, Pérez Jiménez A., Barcelona 2001.

${ }^{10}$ KRADER, L., La formación del Estado, Trad. Jesús Formperosa Aparicio, The Formation of the State, Barcelona 1972, pág. 18.

${ }^{11}$ La edición que manejamos fundamentalmente para D.H. es Dionisio de Halicarnaso. Historia Antigua de Roma, trad. y notas de Alonso A. y Seco C., Madrid 2002. 
El fragmento, poco histórico, sí que puede evidenciar un hecho social: que los botines de guerra pueden tener un uso colectivo atendiendo especialmente a su importancia. Curiosamente, en este caso, es de nuevo el líder a quien le corresponde determinar que bienes quedan afectos a las necesidades comunes del conjunto del grupo.

Por último nos centramos en un fragmento de Virgilio Aen. 9.265, quien afirma que «si vero capere Italiam sceptrisque potiri / contigerit victori et praedae dicere sortem, / vidisti quo Turnus equo, quibus ibat in armis / aureus: ipsum illum, clipeum cristas que rubentis / excipiam sorti/» con lo que se dice que «si logro en suerte adueñarme de Italia y hacerme con el cetro y asignarme el reparto del botín, ¿viste el caballo que montaba Turno?, ¿qué armas rutilantes las suyas? Pues el mismo corcel y su rodela y sus relucientes plumas carmesíes quedarían retiradas del destino del botín».

De este fragmento se deduce otro aspecto interesante: el supuesto sorteo del botín, probablemente entre los miembros del grupo; botín del que, por otro lado, se dice que se adueñará. Esta expresión «adueñarse» tiene más visos de ser una expresión retórica que jurídica, o de la que al menos no puede extraerse consecuencia jurídica alguna en torno a la titularidad. Sin embargo, sí que resulta interesante otro dato: la capacidad del líder para detraer del botín bienes, como es el caso de los spolia.

De lo visto en estos fragmentos pocas conclusiones se pueden sacar en claro, pero sí algunas líneas que van a confirmarse en épocas proto-históricas e históricas y que pueden llegar a confirmarse: a saber, que el líder del grupo guerrero goza de libertad de disposición del botín de acuerdo con las necesidades del momento pudiendo detraer bienes (spolia), si bien, a priori, la inexistencia de organización política exige un reparto del mismo entre los grupos o miembros que forman parte de la partida guerrera y que, dicho reparto, se pueda realizar mediante sorteo.

\section{II.2. La monarquía latino-sabina}

\section{a) Testimonios e interpretación}

Pasamos al estudio de la monarquía latino-sabina el cual nos llevará a épocas pre-urbanas y proto-históricas, alejándonos de lo legendario para avistar poco a poco la luz de los hechos históricos, pues es un hecho contrastado que muchos de esos testimonios lite- 
rarios, especialmente cuando no atendemos a la literalidad de las palabras, empiezan a confirmarse históricamente en los restos arqueológicos. No obstante, hemos de aceptar que no todo es histórico sino que raya, en algunos casos, lo legendario.

Esta situación de incerteza hace necesario contrastar los testimonios de historiadores, analistas, gramáticos romanos etc. con los resultados aportados por las ciencias históricas, arqueológicas, sociológicas o antropológicas con el fin de encontrar una explicación plausible a los testimonios, eliminando lo meramente legendario y reconstruir lo que de cierto hay en las fuentes ${ }^{12}$. Como dice MOMI-

${ }_{12} \mathrm{Al}$ respecto, TORELLI, M., Roma arcaica. Archeologia e storia en Roma Arcaica e le recenti scoperte archeologiche, Milano 1980; CORNELL, T., Alcune reflessione sulla formazione della tradizione storiografica su Roma arcaica en Roma Arcaica e le recenti scopeerte archeologiche, Milano 1980, y en la misma obra conjunta, FREZZA, P., Sulla utilità dei risultati delle recenti ricerche di archeologia e di storia romana per gli studio di storia del Diritto Romano.

Podemos traer a colación la opinión de BIETTI SESTIERI, A. M., L'Archeologia Processuale in Italia, o l'Impossibilità di essere Normali, en Archeologia teorica, X (Firenze 2000) págs. 1-29 en especial pág. 5., que sigue a CARANDINI, al referirse al polémico asunto de la conservación de acontecimientos llamados mitológicos o legendarios.

Los romanos y los latinos, victoriosos frente a los diversos pueblos de la península itálica, preservaron y transmitieron noticias relativas a sus orígenes. Sin embargo, pese a los «adornos», con los que en un momento determinado nos puedan transmitir las fuentes literarias, permanecen o sobreviven lo que nuestra autora llama «i dati strutturali, come ad esempio quelli a proposito di prodigi e fondazioni, che hanno ogni probabilità di essere storicamente veritieri» ${ }^{12}$.

Su afirmación lleva a la autora a aceptar un modelo de estudio, en este caso arqueológico, por el que tratan de dar cierto valor a determinados acontecimientos calificados como legendarios que pueden adquirir verosimilitud mediante la estratificación de los datos históricos, su descodificación y restauración, esto es, eliminar las alteraciones posibles mediante el contraste entre la noticia histórica y el dato arqueológico.

Esta afirmación supone que sí que podemos tener encuenta los testimonios literarios pero que hemos de encontrar un método con el que poder constatar su autenticidad al despojarlos de los añadidos literarios.

Por su parte, dice LÉVY, J., PhLÉVY, J. Ph., Le Probléme des Ordalies en Droit Romain en St. Francisci 2 (1956), pág. 415., respecto a la exactitud de los hechos que trataremos en este trabajo, que "ce qui compte pour nous $n$ est pas l exactitude de 1 évènement: authentique ou imaginaire, dès lors qu il a été consideré comme réel, il a toujours la même valeur paradigmatique». El autor pone el acento en la realidad que tal acontecimiento tiene en la conciencia colectiva.

Poco importa si el hecho acaeció o no exactamente en la realidad tal y como narran las fuentes; lo relevante es la convicción, la creencia colectiva, de que tal suceso acaeció al considerarlo como real y la trascendencia que para esta sociedad puedo tener.

Es una frase sumamente interesante, pues destaca las circunstancias sociales, psicológicas y religiosas que, en un momento determinado, hacen que una sociedad 
GLIANO, a veces, el problema de lo afirmado en las fuentes no es su verdad, sino pretender que sea cierto según una interpretación literal del testimonio.

A mayor abundamiento problemático, a la «inexactitud histórica» cabe añadir la, a menudo, carencia de datos como una dificultad añadida que complica, y mucho, la reconstrucción de cualquier cuadro histórico-jurídico, lo que sólo se puede reconstruir hasta cierto punto lógico si recurrimos de forma transversal al auxilio de otras ciencias.

Veamos pues, en primer lugar, los aspectos jurídicos que se desprenden de las fuentes literarias siguiendo el orden tradicional de los reyes latino-sabinos y, en primer lugar, de la figura legendaria de Rómulo ${ }^{13}$.

Como hemos dicho, que la narración sea con mucho legendaria no es óbice para pensar que lo relatado por Livio no responda a unas circunstancias sociales determinadas que pudiesen caracterizar una época. Por ello, sin atender a la literalidad de las palabras, veremos cómo lo afirmado para "Rómulo» resulta aplicable al modelo de sociedad que se supone existió en el Lacio en el VIII a.C.

Dice Livio ${ }^{14}$ que "hinc robore corporibus animis que sumpto iam non feras tantum subsistere, sed in latrones praeda onustos impetus facere pastoribusque rapta dividere, esto es, que cobraron con ello vigor sus cuerpos y sus mentes, y no solo acechaban a las fieras, sino que atacaban a los salteadores cargados con botín, se lo arrebataban, y lo repartían entre los pastores. Del texto se deduce un aspecto interesante: que el botín, en este caso, lejos de considerarse como algo que pertenece a todos como entidad, es propio de grupos no organizados políticamente entre sí.

En esta misma idea insiste Dionisio de Halicarnaso ${ }^{15}$ cuando narra la guerra contra los camerinos y afirma que, tras la derrota de estos a manos de los romanos, «les quitaron las armas, les castigaron con la pérdida de un tercio de su territorio, que dividieron entre los suyos». Ante la resistencia guerrillera de los camerinos, tras una segunda derrota «dividieron todos sus bienes entre sus ciudadanos».

considere hechos legendarios como existentes. En todo caso, tales hechos tienen un sustrato de realidad sobre el que se construyen las leyendas, cosa que no ocurre con los mitos.

13 MARTÍNEZ-PINNA, Los orígenes de Roma, Madrid 1999, pág. 170. CORNELL.

14 Liv. 1.4.9.

15 D.H. 2.50.4-5 
Interesante resulta el contexto previo en que Dionisio de Halicarnaso nos sitúa el evento contra los camerinos: la configuración de la comunidad pre-urbana y la «construcción» o «disposición» de «edificios» (templos o santuarios) o espacios comunes (Foro) a los habitantes de las colinas. Por otro lado, nos indica de forma clara que botín de guerra se reparte entre dos comunidades distintas.

La existencia de ciertos elementos o edificios comunes nos tendría que hacer pensar en la necesidad de que existiesen recursos destinados al pago y mantenimiento de los mismos; recursos que sólo se pueden obtener por vía de las sanciones, tributos o botín de guerra. En este caso, creemos que andaríamos bastante desencaminados si pensásemos que tales templos se corresponden con la imagen que tenemos actualmente de ellos, sino que más bien deberíamos pensar en lugares de culto ${ }^{16} \mathrm{o}$ en espacios comunes no construidos o urbanizados. Por ello, cuando nos informan de templos erigidos en esta época, habríamos de pensar en un tipo de estructura religiosa correspondiente a la época y no poner en duda que una construcción religiosa pudo existir.

El reparto del botín evidencia la ausencia de comunidad política urbanizada, tal y como se manifiesta de nuevo en DH. 2.53.4 donde se dice que tras tomar la ciudad de Fidenas se repartió el terreno entre sus hombres. Esta afirmación es una muestra más de dos ideas que se vienen pergeñando durante estas etapas pre-urbanas y protourbanas: que la ausencia de comunidad política hace que el reparto se haga entre las grupos que conforman el grupo guerrero y que el líder asume la dirección del reparto, pues en todos los fragmentos se dice que es el rey el que procede al mismo.

En un sentido similar se muestra Plutarco cuando dice que Rómulo (Rom. 17.1-2), tras la victoria sobre los habitantes de Fidenas, Crustumerio y Antemna, repartió el territorio entre su gente y que devolvió bienes, una vez recuperados, a quien los había perdido.

En cuanto a Tulio Hostilio y Anco Marcio poco más se puede decir de lo afirmado anteriormente, pues queda claro que la situación jurídica del botín es la misma que la señalada para Rómulo.

En particular, de Tulio Hostilio nos informa DH. 3.33.4 al decir que en las escaramuzas contra los latinos «se invadían el territorio

${ }^{16}$ LINKE, B., Von der Verwandschaft zum Staat. Die Entstehung politischer Organizationsformen in der frührömischer Geschichte, Franz Steiner, Stuttgart 1995, pág. 125. 
mutuamente e intercambiaban rehenes»y, por último, respecto a Anco Marcio, dice DH en 3.41.5 que obtuvo un gran botín.

Parece claro que en los textos estudiados, el botín se reparte inicialmente entre aquellos grupos que contribuyen a la guerra para compensar o quizás para mantener su posición social en el grupo.

Sin embargo, pese a la aparente claridad de los textos, la lectura de algunos testimonios plantean dudas, pues pueden hacernos pensar en la existencia de un destino público de lo obtenido en el botín.

El primero nos los refiere Dionisio de Halicarnaso ${ }^{17}$ cuando afirma que Rómulo, en la guerra contra los antemates, destinó parte del botín de guerra más escogido para los dioses, concretamente a Júpiter Feretrio, a quien se le consagran los despojos opimos (los despojos del jefe enemigo obtenidos por el jefe romano rey o general, mientras que las de un jefe enemigo obtenidos por comandante o un soldado se ofrecen respectivamente a Marte (dios de la guerra) y a Quirino (dios de la producción, el cultivo, la cultura) ${ }^{18}$. El hecho de que se dé tal destino a estos bienes puede hacernos pensar que podría existir una comunidad política y que el botín estuviese afecto a un interés común, como es la pax deorum.

Sin embargo, creemos que este testimonio puede tener una explicación más lógica, pues creemos poder interpretar el acto en el ámbito de las funciones que son propias del rey como mediador entre el mundo de lo divino y de lo humano y a quien le corresponde mantener la rectitud y equilibrio de tales relaciones.

De hecho, se puede entender que, precisamente, el acto de destinar los bienes a la "construcción» de un templo o que se consagrasen a los dioses, puede tener más que ver con una decisión "política» que administrativa, en el sentido de que debió de servir para afianzar su poder de naturaleza religiosa y, con ello, también afianzar la unidad religiosa de la federación del collis y por tanto de la comunidad preromana. De hecho, según BAYET ${ }^{19}$, Júpiter aparece como dios de las armas o del poder mágico de la realeza.

El segundo testimonio dudoso se refiere a la guerra contra Veyes. Dioniso de Halicarnaso en 2.55.5 dice que Rómulo impuso las siguientes condiciones: 1) Entrega a los romanos del territorio contiguo

$17 \quad 2.34 .1$

18 DUMEZIL, La religión, pág. 190, 191. BAYET, Histoire, pág. 118.

19 BAYET, Histoire, pág. 26. 
al Tiber; 2) Abandonar las salinas situadas junto a la desembocadura del río; 3) Entregar cincuenta rehenes.

De la expresión «romanos» como aquellos a los que se entrega un territorio, no se puede deducir un concepto unitario, como pueblo, del que se puedan considerar titulares como tal, pues cabría pensar que, como ocurrió en la toma de Fidenas, tales territorios fuesen inmediatamente repartidos entre los grupos gentilicios.

Respecto a las salinas, hemos de considerar la posibilidad de que las fuentes no sean del todo exactas, pues según ALFÖLDY ${ }^{20}$, la toma de las salinas por parte de los romanos no se produjo antes del V a. C.

\section{b) Justificación de la interpretación}

Visto lo antedicho, vamos a ver como se puede justificar lo afirmado en los textos y que aparece como regla general: el normal reparto del botín entre los grupos gentilicios.

Para ello, volvamos pues a la pregunta que nos hacíamos inicialmente: ¿cómo podemos explicar la razón de este destino? A nuestro modo de ver, un primer argumento lo hallamos en el modelo de sociedad pre y proto-urbana.

El hecho de que se distribuya normalmente entre el pueblo o se permita el saqueo a los soldados, avala la teoría de aquellos que opinan que el botín de guerra pertenecería en esta época a los miembros de la comunidad ${ }^{21} \mathrm{o}$ a estructuras sociales en las que se agrupaban los individuos, gentilidades y que conformarían el modelo evolutivo social que JOHNSON y EARLE llaman "grupos locales», esto es, un modo de organización política formado por subgrupos de unidades familiares autónomas que se mantienen unidos por mecanismos culturales que combinan un incipiente patrón emergente de liderazgo con un extenso ceremonial ${ }^{22}$.

Esta última es, en nuestra opinión, la tesis más plausible: a saber, que entre los miembros de los grupos gentilicios se reparte el botín durante este periodo pre-«estatal» o proto-«estatal» dada una

${ }^{20}$ MARTÍNEZ-PINNA, Los orígenes de Roma, pág. 162.

${ }^{21}$ KLINGMÜLLER, F., Die Idee des Staastseigentim im römischen Provinzialboden en Philologus, 69, Dieterische Verlagsbuchhandlung, Leipzig 1910, págs. 71-113 en especial pág. 72 .

22 EDER, W., Servitus publica, Franz Steiner Verlag, Stuttgart 1980, pág. 128. JOHNSON-EARLE, La Evolución, pág. 133. 
constitución política de carácter eminentemente gentilicia y guerrera $^{23}$ que participaba activamente en su totalidad de dicha actividad. Probablemente, estemos hablando de una sociedad política en la que el papel del rey, siendo importante, queda marcado por los grupos gentilicios que, a modo de asociaciones, conforman la sociedad y limitan el poder del rey, gozando con ello de una gran autonomía.

La prueba arqueológica ${ }^{24}$ de esta práctica social la encontramos en las lanzas en miniatura encontradas en las tumbas del II y principios del III período Lacial (X-VIII a C.), y que responden verosímilmente al papel predominantemente social que de la función guerrera asumían los hombres, jóvenes y adultos ${ }^{25}$, dado que la mayoría de las lanzas en miniatura se han encontrado en tumbas pertenecientes a personas de esta edad.

No estamos pues de acuerdo con la tesis de $\mathrm{BONA}^{26}$, para quien el botín de guerra, las res hostium, eran propiedad de aquel que adquiriese la posesión. Así mismo, trae a colación un fragmento de Polibio 10.17.1-4 en que se hace referencia al juramento militar con el que, entre otras cosas, parece que se pone freno a la rapacidad desenfrenada de todo soldado, ávido de ver compensado su esfuerzo, su sacrificio y el riesgo de su vida, con los despojos del enemigo.

En nuestra opinión, la tesis de BONA resulta insuficiente para explicar la época monárquica, pues creemos que no tiene en cuenta su-

${ }^{23}$ ROLDAN, J. M., Historia de Roma, Ediciones de la Universidad de Salamanca, Salamanca 2005, pág. 71

${ }^{24}$ SCARANO USSANI, Il Significato, pág. 321 y 322 nt.10.

25 PERUZZI, Aspetti Culturali del Lazio Primitivo, (Firenze 1978), pág. 128, afirma que el hasta, la lanza, no sólo es el arma «nacional» sino que desde el inicio fue designada de esta forma. Esto afirmado con relación al curis -quiris sabino. BIETTI SESTIERI, L'Archeologia, págs. 19, 21. En el estudio de las tumbas de incineración de la Osteria dell Osa cataloga las edades y condición de los portadores de lanza en el ajuar sepulcral. Así 126 (número del sepulcro) adulto joven (20-30 años), 142 adulto joven (25-30), 128 joven (17-18), 98 adulto-joven (20-25), 127 adulto genérico (20-40), 129 adulto genérico (20-40), 131 adulto o maduro $(40+), 135$ adulto genérico (20-40), 139 adulto genérico (25-45), 308 adulto o maduro (40?), 352 adulto-maduro $(35+10)$. Portadores de espada 130 adulto-joven (20-30), 137 adulto genérico (20-40) y 158 adulto joven, lo que respondería a un tipo de organización tribal muy simple que podría ser similar que la del Latium vetus en época coetánea.

${ }^{26}$ BONA, F., praeda en ED, 34, Giuffré Ed. Milano 1985, pág. 911-916, en especial, pág. 911. Al respecto también del mismo autor, Preda di guerra e occupazione privata di res hostium en SDHI 25, Pontificia Universtá Lateranensi, Roma 1959, págs. 309369. De ahí la interpretación de la sentencia de Gayo 4.16 con la que se fundamentaba el título de propiedad de las cosas tomadas al enemigo a causa del saqueo y devastación de sus ciudades y tierras. 
ficientemente los modos en que se organiza políticamente Roma a lo largo de este periodo y su trascendencia en orden a la posible titularidad pública del botín de guerra.

El argumento que aduce de Gayo evidencia uno de los modos más antiguos de adquisición de bienes por causa de guerra, pero ello no explica las facultades que pudo tener el monarca en orden a la disposición y destino del botín, así como la detracción de bienes que formen parte del mismo, como se evidencia en las fuentes. Además, creemos que esta opción quedaría rechazada si aceptamos lo que nos dicen las fuentes literarias, pues de éstas se infiere de forma palmaria que el saqueo y el reparto del botín se hace siempre bajo la autoridad y el poder de decisión del rey que es quien dirige la batalla y autoriza, en su caso, el reparto del botín entre los soldado permitiendo el saqueo de los campamentos y ciudades.

Pensamos que el hecho de que los testimonios literarios evidencien esta norma, excluye que los soldados y los grupos de gentilidades, adquiriesen de forma directa (mediante el saqueo) los botines de guerra salvo que el rey lo permitiese, manifestando de este modo el poder directo de disposición del monarca sobre el botín.

Por otro lado, el argumento aducido con la tesis de Polibio, evidencia una máxima lógica propia de toda comunidad militarmente organizada o de toda disciplina militar, esto es, la necesidad de que el reparto del botín esté sujeto a ciertas reglas que mantengan el orden en el seno del ejercito con el fin de evitar el caos cuando los soldados se lancen, ávidos, a por los despojos del enemigo. Esta afirmación lógica, si bien debe ser tenida en cuenta, también es necesario contextualizarla en un momento determinado del desarrollo histórico y político.

Sigamos con algunos argumentos que creemos que permiten hacer plausible nuestra tesis de una distribución de botín entre los grupos gentilicios durante las épocas pre-y proto-urbanas.

Esta sociedad se configuró a partir de una paulatina federación de aldeas independientes que conformaban vicus y pagus ${ }^{27}$ en los que se

27 DE FRANCISCI, P., La comunità sociale e política romana primitiva en SDHI 22 (1956), pág. 1-86 en especial pág. 41; LAFFI, U., Problemi della organizzazione paganco-vicana nelle aree abruzzesi e molisane en Tahenaeum 52 (1974), pág. 336-339 en especial pág. 337 donde desarrolla el régimen político y social de los vicus y pagus en la Italia prerromana y romana, donde el vicus sería una res publica autónoma con órganos propios (magistrados y asambleas), con un territorio definido con bienes patrimoniales propios. Paganos y vicanos reunidos en asambleas tomaban las decisiones 
desarrollaba políticamente la organización político-gentilicia, lo que no supuso renunciar a su propia autonomía en su territorio -pagus- y en su aldea-vicus-, y preludiando los órganos fundamentales de la constitución política antigua. No obstante, el hecho de que pudiesen existir intereses comunes hacían que por tal «federación», las gentes y sus jefes gentilicios se viesen obligados a someterse a un jefe superior -el rex-sacerdos-.

Nos encontramos en una etapa en la que, a lo sumo, Roma se encuentra en un estadio proto-urbano, lo que significa que política y urbanísticamente estaríamos ante una sociedad que empieza a sustituir la cabaña por la casa de piedra y a planificar racionalmente de forma elemental el espacio habitado con vías internas y lugares destinados al uso público ${ }^{28}$ a partir de la segunda mitad del siglo VII, pero que alcanzará un gran desarrollo con la monarquía etrusca. Para KRISTIANSEN ${ }^{29}$, estaríamos ante un proceso de formación del Estado que llevaría a una identificación cultural y social con un territorio político y asociado a una diversificación análoga en las sepulturas, donde dominan las elites guerreras que serán sustituidas paulatinamente a partir del 700 a.C. por tumbas guerreras colectivas.

Por consiguiente, dado que el botín de guerra no se destinaba al populus al no existir políticamente, sino a los diversos grupos que conformarán posteriormente parte del mismo, hemos de considerar que el botín de guerra no se lo atribuía el monarca latino sabino, pues las fuentes no se refieren a ello de forma clara, en principio, lo que no excluye ni muchísimo menos que no pudiese participar de él.

El hecho pues de que, quizás se reparta el botín entre los grupos que forman el «ejercito», sea por una práctica común, sea quizás por el sentido de la lucha como actividad común realizada por grupos federados o independientes, encuentra un segundo argumento en la justificación del poder -y el fundamento del mismo- y las facultades reales.

Respecto al poder del rey y sus facultades, la cuestión varía entre si se le atribuyen funciones preferentemente militares, religiosas o

que regulaban en la práctica todos los ámbitos de la vida administrativa y financiera... Regidos por un magistrado de la comunidad... en un plano similar a los municipios. MARTÍNEZ-PINNA, J., Los orígenes del ejército romano: Estudio de las formas premilitares en su relación con las estructuras sociales de la Roma primitiva, Tesis doctoral. Universidad Complutense de Madrid 1981, pág. 93, 102, 107, 118, 119.

${ }_{28}$ MARTÍNEZ-PINNA, Los orígenes de Roma, pág. 125,199. 201.

${ }^{29}$ KRISTIANSEN, K., Europa antes de Europa, Península, Barcelona 2001, pág. 
políticas, si bien no se excluyen entre sí. ORESTANO ${ }^{30}$, atribuye funciones prevalentemente militares que lo hace considerar un ductor cuyo poder se fundamenta en el carisma, al igual que DE FRANCIS$\mathrm{CI}$, tesis que también sostiene DE SANTIS ${ }^{31}$ y que, como tal, le atribuye facultades soberanas en la dirección del ejercito y en la disposición sobre el botín. Otros como $\mathrm{COLI}^{32}$, acentúan el carácter político

En nuestra opinión, creemos que hemos de partir del origen indoeuropeo que tiene el rex ${ }^{33}$ romano, lo que se constata etimológicamente pues los términos son coincidentes en las áreas oriental (rajá) y occidental (latín o céltico).

Para BENVENISTE ${ }^{34}$, el término encierra un significado mucho más religioso (sacred king al que se refieren GRAMKRELIDZE, T.IVANOV, V.) que político. Hay que ver menos al soberano como aquel que traza la línea, la vía seguir, que encarna, al mismo tiempo lo que es recto ${ }^{35}$. Su misión no es mandar, ejercer un poder, sino fijar unas reglas, determinar lo que es recto en sentido propio.

El rex, en origen, definido según la tesis de BENVENISTE, se emparenta más con un sacerdote que con un soberano que simboliza

30 ORESTANO, R., I fatti di normazione nell esperienza romana arcaica, Torino 1967, pág. 129. Alguien que por sus cualidades destacase no sólo por su valor, sino por su conocimiento de las técnicas sagradas y conocedor de las señales divinas (capacidad augural).

31 DE SANCTIS, Roma. Dalle Origine alla monarchia, reimp. Firenze 1980, pág. 351.

32 COLI, U., Regnum (Roma 1951).

33 DEVOTO, La lingua, pág. 17. Nos explica el fenómeno por el que determinadas palabras, especialmente de origen estatal y religioso, que se encuentran en el extremo occidental son coincidentes y conservan elementos comunes con la oriental, mientras que en la zona central han perdido su forma correspondiente. Tal es el caso del término rex. VILLAR, Los indoeuropeos, pág. 394.

${ }^{34}$ Cic. De Div. 1.40.89BENVENSITE; El vocabulario, págs. 246-247. Ahora bien, como apunta VILLAR, hay que tener cuidado, pues cabe concebir la figura del rey con un poder para mandar (soberano) sino hay que entender sus facultades en un sentido material primario «tender una línea recta» y como metafórico, utilizado para designar la ley o el derecho, lo que se traduciría en considerar que el rey tiene potestad para dar normas jurídicas y hacerlas cumplir. Para DE FANCISCI, Dal «regnum» alla «res publica», en SDHI, 9 (1943), 150-166 en especial pág. 152 se trataría de un poder carismático.

35 GRAMKRELIDZE-IVANOV, Indo-european, pág. 654, afirman que proviene de la raíz *rek- y que significa, direct, correct, straigthen, even out. En un sentido opuesto, más vinculado al carácter carísmático, DE FRANCISCI, Primordia civitatis, BERNARDI A. L'Interesse di Caligola per la Successione del rex nemorensis la arcaica regalità nel Lazio, en Athenaeum 31 (1953), pág. 273-287 en especial págs. 278-279. 
la unidad y el bienestar de la sociedad (lo que se evidencia en Roma en el rex sacrorum y la Regia). Esta noción estaba unida a la existencia de los grandes colegios sacerdotales que tenían como función perpetuar la observancia de los ritos.

Por consiguiente, será necesaria una larga evolución y una transformación radical para llegar a la realeza de tipo clásico, fundada exclusivamente sobre el poder, y para que la autoridad política se fuese haciendo poco a poco independiente del poder religioso, que seguía a tribuido a los sacerdotes: el paso del rey sacerdote al rey militar.

En este modelo evolutivo, vemos como casa perfectamente el papel que LINKE ${ }^{36}$ atribuye al monarca y que puede ser considerado como una especie de liderazgo incipiente. Se comprendería esta facultad en el contexto de la capacidad que, tradicionalmente, le atribuirían los pueblos indoeuropeos al monarca, como una disposición de quien determina el destino de los bienes en cuanto que tiene la capacidad de fijar las reglas de lo que es recto en sentido propio tanto material como simbólicamente ${ }^{37}$. Según $\mathrm{DEVOTO}^{38}$, estas facultades tendrían especial relevancia en el ámbito de la actividad militar, de las razias, donde adquirirían una mayor significación e importancia; un poder más pleno (frente a las limitaciones que pudiese tener en otros ámbitos, por ejemplo, religiosos). En opinión de MARTÍNEZPINNA $^{39}$, la monarquía latina, por razones económicas y sociales, es el producto de la fusión de las funciones sacerdotales y militares.

Con todo, y pese a que no nos encontramos con una sociedad plenamente descentralizada, pues a partir del siglo IX a. C. se produce una centralización del poder en la comunidad romana origina-

${ }^{36}$ LINKE, B., Von der Verwandschaft zum Staat. Die Entstehung politischer Organizationsformen in der frührömischer Geschichte, Franz Steiner, Stuttgart 1995, págs. 49, 53, 54 .

37 Como dice BENVENISTE, E., Vocabulario de las instituciones indoeuropeas, Madrid 1983, págs. 246-247, el rey indoeuropeo es mucho más religioso que político. Hay que ver menos al soberano que aquel que traza la línea, la vía seguir, que encarna, al mismo tiempo lo que recto. Su misión no es mandar, ejercer un poder, sino fijar unas reglas, determinar lo que es recto en sentido propio. De suerte que el rex, así definido, se emparenta más con un sacerdote que con un soberano. Esta noción estaba unida a la existencia de los grandes colegios de sacerdotes que tenían por función perpetuar la observancia de los ritos. Ha sido pues necesaria una larga evolución y una transformación radical para llegar a la realeza de tipo clásico, fundada exclusivamente sobre el poder, y para que la autoridad política se fuese haciendo poco a poco independiente del poder religioso, que seguía a tribuido a los sacerdotes. DEVOTO, G., Origine indoeuropee, Firenze 1962, pág. 318.

38 DEVOTO, Origine, pág. 318.

39 MARTÍNEZ-PINNA, Los orígenes del ejercito romano, pág. 240. 
ria, la potestas regis es una 'treuhänderische potestas', esto es, una especie de poder fiduciario análogo a los particulares -Hausgemeinschaften- que tendrían los miembros de la comunidad y con el que desempeñar sus funciones como "señor simbólico», como primus inter pares bajo quien se mantiene la unidad de la comunidad en armonía con el orden Natural, carente de un poder completo -umfassende Amtsgewalt- sino contextualizado en función de las normas sociales.

Lo afirmado, creemos que puede confirmarse en un tercer argumento que evidencia que nos encontramos en una sociedad donde las clases aristocráticas y los grupos gentilicios, que habían adquirido relevancia política y social durante el siglo VII, gozan de preminencia ${ }^{40}$. Tal creemos que es el modo de entender el iniciático rito de los fetiales, donde la reclamación al pueblo enemigo y la declaración de guerra se hace en nombre del pueblo romano de los Quirites, y por tanto, según el derecho de los mismos, esto es, según TORRENT ${ }^{41}$, según las mores maiorum comunes a los iura gentilicia a todos los patricios: el primitivo núcleo de la aristocracia en armas, ero entendido como conjunto de individuos ${ }^{42}$. Obsérvese también la importancia que desempeñaba el pater patratus en la declaración de guerra como representante del Senado.

Un cuarto argumento lo hallamos en el destino del botín obtenido con el pillaje o las "guerras», pues cabría plantearse si el botín se destinaba a los gastos de construcción de obras religiosas, civiles o militares, en la sociedad proto-urbana, en tanto que ello evidenciaría la posible existencia de un caudal común al pueblo romano y, a su vez, políticamente, determinaría la existencia del pueblo romano.

Sin embargo, surge al respecto una duda y es la propia existencia de ciertas obras públicas y religiosas asociadas a la época de los reyes latinos-sabinos. Si bien parece cierto, como hemos afirmado, que

${ }^{40}$ Respecto al papel de las gentes en la organización del ejército, TAGLIATELA SCAFATI, M., Appunti sull ordinamento militare di Roma Arcaica. Con una lettura di Dion. 3.71.1 e note a Flor 1.1(5)2 e 1.1(1).15 en Ricerche sulla organizazzione gentilizia romana, 2 Napoli 1988, págs. 39-91. Así como la obra de FRACCARO, P., Storia del antichissimo essercito romano a'l età dell ordinamento centuriato en Oposcula 2 (1957) $288 \mathrm{ss}$

41 TORRENT, A., Conceptos fundamentales del ordenamiento jurídico romano, Salamanca 1973, pág. 55; Derecho Público Romano y sistema de fuentes, Oviedo 1982, pág. 117. MINIERI, L., Mores e decreta gentilicia en Ricerche sulla organizazzione gentilizia romana 3, Napoli 1995, págs. 123-168 en especial pág. 136. DE MARTINO, Storia, 1 pág. 14. ORESTANO, v. gens en NNDI 7 (1957), pág. 225-228 en especial 227.

42 CATALANO, Populus, págs. 105-107. 
en época de Anco Marcio, Roma alcanza como máximo un estadio de desarrollo proto-urbano, este estadio hace difícil plantear la existencia de grandes obras que impliquen un gasto al que destinar el botín de guerra.

Esta constatación tiene una importancia capital, especialmente por lo que se refiere a la pavimentación del Foro, ya que es una evidencia material clara de la existencia de un populus como entidad política y, por tanto, de que se pueda afirmar que el botín pudiera ser una res in patrimonio populi.

Un quinto argumento nos llevaría a ver no existe un populus como cuerpo social cívico y relacionado con el anterior a la urbanización como materialización de tal concepto político quedando en un estadio proto-urbano.

Creemos que un referente esencial para poder hablar del populus como sujeto de derecho de una res in patrimonio es la ciudad y su formación (urbanización) y ello por dos razones. La primera materialmente, pues desde un punto de vista económico la urbanización de la ciudad exige que los recursos obtenidos en el transcurso de las guerras deban jugar un papel esencial y, la segunda, porque la ciudad existe cuando "se identifica a su cuerpo cívico con los ciudadanos» y éstos «adquieren conciencia cívica, lo que se materializa de forma interrelacionada en las instituciones políticas y sociales, en la organización de la vida religiosa y naturalmente en la planificación del espacio urbano» ${ }^{43}$, lo cual se hace patente en la sistematización del Foro, el cual albergará edificios de claro carácter cívico y religioso como son la Regia, el templo de Vesta, el Comicio y el santuario de Jupiter Optimus Maximus. Esta sistematización tiene, en palabras de MARTÍNEZ-PINNA ${ }^{44}$, tanto coherencia interna urbanística como evi-

${ }^{43}$ MARTÍNEZ-PINNA, Los orígenes, pág. 133.

${ }^{44}$ MARTINEZ-PINNA, Los orígenes, pág. 133. KOLB, F., La ciudad en la antigüedad, trad., Elena Bombín, Gredos, Madrid, 1992, pág. 11. La ciudad aparece como el lugar en el que se concentran los logros materiales y espirituales de la civilización humana y desde el que se dirigen las actividades políticas, sociales, culturalesespirituales y económicas. La historia de la humanidad, en esencia, desde el comienzo de las culturas superiores, es la historia de la ciudad.

WEBER, M., Die Stadt en Archiv für Sozialwissenchaft und Sozialpolitik, 47 (1921), pág. 621. Condiciones para que exista una ciudad: existe una sociedad en sentido económico donde la «población allí asentada satisface una parte económicamente esencial de sus necesidades de consumo diario de mercado propio, y en gran parte mediante productos que la población allí asentada o de las tierras próximas produce o ha obtenido de otro para su venta en el mercado». Es por tanto, esencial para la ciudad un mercado local regulado por ella. 
dente ideología propia. Por tanto, desde un punto de vista político, la urbanización, especialmente la construcción de edificios públicos destinados al uso común y cívico, es el símbolo de la formación de la comunidad política, y este es el papel que desempeñaba el Foro como centro cívico y de mercado, y el Comicio.

De acuerdo con lo afirmado, observamos cómo en ningún texto se dice, salvo la noticia relativa a la ofrenda de Rómulo a Júpiter, que el botín de guerra se destine a tales fines, lo que puede implicar que o bien no se destinaba a tal fin o sencillamente que no había tales obras públicas a las que se refieren las fuentes.

Precisamente, esta es la idea que parece que se corrobora por la arqueología, pues en general, y si seguimos a GJERSTAD ${ }^{45}$, el proceso de urbanización de la ciudad se inicia en el periodo arcaico, concretamente, a partir del siglo VI a.C., sustituyendo las construcciones propias de época proto-urbana y pre-urbana, lo que conecta con la construcción de los primeros edificios públicos y lugares de culto. Destaca CORNELL ${ }^{46}$, que a finales del periodo orientalizante se pro-

Ciudad en sentido político-administrativo. Este implica una situación tributaria especial del territorio urbano (en comparación con el de fuera de la ciudad) la condición de la ciudad como fortaleza y lugar de defensa y la obligación de servicio militar por parte de sus habitantes. CALZADA GONZÁLEZ, A.,La demolición de edificios en la legislación municipal (siglos I a. C.-I d.C.)», SDHI. LXXVI. 2010. 115-134. Evidentemente, WEBER, ve la forma más elevada de la ciudad en la comunidad urbana con sus ciudadanos...En su opinión de las comunidades urbanas de este tipo sólo podían ser asentamientos "con un carácter industrial -comercial al menos relativamente fuerte».

Por otra parte, el concepto de WEBER ha penetrado en la moderna definición de ciudad basada en la geografía del asentamiento, que la determina partiendo de su imagen exterior y de su función como «lugar central» (la unidad topográfica, el tamaño y la densidad de las construcciones en el área de asentamiento, la sensación resultante, aunque vaga, de un número considerable de habitantes, la diferenciación y calidad de construcción (edificios públicos monumentales, barrios industriales, etc.) ...Los demás rasgos que se unen con la ciudad, en concreto una notable diferenciación de la población, social y de oficios, que en general sólo es posible si aparecen por lo menos las funciones de centro respecto a un entorno.

Al respecto, DILCHER, G., Rechtshistorische Aspekte des Stadtbegriffe en JANKUHN, H.-SCHLESINGER, W.-STEUER, H., Vor- und Frühformen der europäischen Stadt im Mittelalter, 1, 1973, págs. 12-32. FINLEY, M. I. Die antike Wirtschaft, 1977, pág. 146-178. HAMMOND, M., The city in the ancient world, 1972. MUMFORD, C., Die Stadt, 1961. UCKO, P. J.-TEINGHAM, R.-DIMBLEBY, G. W., Men, Settlement and Urbanism, 1972. VANCE, J. E., This sceneof man. 1977; VITTINGHOFF, F., Stadt und Urbanisierung in der griech-röm Antike en Historische Zeitschrifit, 226 (1978), págs. 547-563.

45 GJERSTAD, Early, IV.2, pág. 581.

46 CORNELL, T. J., Los orígenes de Roma. C. 1000-264 a.C. Italia y Roma de la Edad del Bronce a las guerras Púnicas, Critica, Barcelona 1999, pág. 122. 
dujeron notables cambios. Concretamente, a mediados del siglo VII, con la demolición de las cabañas de la vía Sacra y del Equus Domitiani, y a comienzos del siglo VI Roma dejó de ser el primitivo poblado de cabañas, proceso iniciado en época proto-histórica con la concentración de los grupos de aldeas, para convertirse en una comunidad verdaderamente urbana, lo cual casa con las construcciones auspiciadas por los reyes y testimoniadas en las fuentes literarias, especialmente, en lo tocante a la fundación de templos ${ }^{47}$.

Lo afirmado se puede constatar con las primeras labores de pavimentación y drenaje del Foro, junto con la construcción de la Cloaca Máxima y la canalización del rio Velabro, que habría que situarlas a partir del 630 a. C. ${ }^{48}$, así como la Regia ${ }^{49}$ y el Comicio, con fines políticos, en torno al 600 a.C. y el Capitolio (Júpiter) a inicios del VI a.C. ${ }^{50}$.

En términos generales, hemos de pensar que la datación de tales construcciones chocan con las supuestas construcciones que las fuentes atribuyen a los reyes latino-sabinos y que, al menos, hemos de situarlas en una fase que no se corresponde propiamente con lo que entendemos por "grandes construcciones».

Así tenemos la supuesta muralla de Rómulo, pues según COARELLI $^{51}$, habría que situar las fortificaciones más antiguas en el siglo VI a.C. (atribuibles a Tarquino Prisco y Servio Tulio).

A Numa se le atribuye la construcción del templo de Vesta (Plut. Num.11); el templo a la Fe Pública o de Terminus de los que se dice que los gastos fueron cubiertos a expensas del Estado (DH.2.75.3) y la edificación de la Regia (Plut. Num. 14). Respecto al templo de Vesta, GJERSTAD sitúa su construcción entre 525-475 a.C. ${ }^{52}$, señalando que el culto se prestaba, anteriormente, en una cabaña -typical Iron Age huts used in pre-urban Rome- de barro y adobe ${ }^{53}$.

47 DRUMMOND, A., Rome in the Fifth Century I. The social and economic framework: II, The citizen community, en The Cambridge Ancient History 2 (1989), pág. 22.

${ }^{48}$ Liv.1.38.6-8; DH:3.67.5. GJERSTAD, Early Rome III, 1960, págs. 79-83; 132-138. AMPOLO Dialoghi di archeologia, 2 (1980), págs. 166-167.

49 Pudo ser, siguiendo la opinión de COARELLI, Foro Romano I: Periodo arcaico, Roma 1983, un complejo de edificios destinados tanto al culto que contenía la residencia del rey y los cultos familiares (Vesta, Lares-Penates, Marte y Ops Consiva).

${ }^{50}$ MARTÍNEZ-PINNA, Los orígenes, pág. 206.

51 COARELLI, Roma, pág. 10-11.

52 GJERSTAD, E., Early Rome IV.2, Lund 1966, pág. 385.

53 GJERSTAD, Early IV.2, pág. 499 IV.1, pág. 45. 
Respecto al templo de la Fides, sin dejar de lado la antigüedad e importancia pública del culto como factor unificador de las conductas de quienes conforman un grupo -entre las gentes-, en tiempos de Numa fue, probablemente, un sacellum; o sacrarium (Liv.1.21.4; Flor.1.2.3), un pequeño santuario transformado posteriormente en templo por A. Colatino y restaurado por E. Escauro (III a.C. $)^{54}$.

De lo afirmado, no se puede pues deducir ni la construcción de un templo ni que existiese un populus sino que nos encontraríamos en esa fase de concentración donde los lazos religiosos, entre otros, son esenciales, pues contribuyen a la ligazón social ${ }^{55}$.

Algo similar puede entenderse respecto al santuario -sacellum ${ }^{56}$ Terminus en el Capitolio, cuyo culto es antiguo y tiene como fin proteger los límites de las propiedades. Nada indica pues que exista un pueblo sino que puede tratarse sencillamente de establecer medios de protección a los repartos de tierra al sancionarlos religiosamente.

Sí que indican, por el contrario, comunidad de creencias y, por tanto, vínculos religiosos que unificarán y se definirán políticamente poco a poco, entre grupos asentados en pagus e independientes, pues el magister pagi aparece como guardián de los términos ${ }^{57}$.

En lo tocante a la Regia, cabe aceptar que fue construida en torno al 575 a.C. o 625-600 a.C, si bien es cierto que había previamente un complejo de cabañas del VIII a.C. ${ }^{58}$, según GJERSTAD de barro y adobe, que era probablemente lo que pudiese atribuirse a Numa, y que fue destruido en torno al VI a.C.

Por lo que toca a Anco Marcio, y la realización de «obra pública» a la cual pudo destinar parte de los botines, hemos de apuntar que, en primer lugar, se dice que amuralló el Aventino o la Fortificación del Janículo, lo cual resulta complicado de aceptar pues sólo a partir de la época arcaica, momento en que Roma empieza a urbanizarse, es cuando nos encontramos con fortificaciones hechas de albañilerías

${ }^{54}$ DUMEZIL, G., La religion romaine archaïche, Paris 1966, 388, 390. GUILLEN, J., Urbs Roma, 3 La religión y el ejército, Salamanca 2004, pág. 243. LATTE, K., Römische Religiongeschichte, München 1992 (reimp.1962), pág. 237. OTTO, v. Fides en PW, 12.1/2 1909, pág. 2281-2285 en especial pág. 2281-2282.

55 BAYET, J., Histoire politique et pshycologique de la religion romaine, Paris 1969, pág. 115, 141 ss.

${ }^{56}$ Liv.1.55.3-4.

57 GUILLEN, Urbs III, pág. 271.

58 CORELLI, F., Il Foro Romano 1, Roma 1983, págs. 61-62; GJERSTAD, Early IV.2, pág. 383. 
(toba capellaccio) que durante la época anterior difícilmente podrían realizarse, pues desconocían la técnica del revestimiento mediante piedra, por tanto, la defensa parece que era más bien natural, quizás agger $^{59}$ o sencillamente hablaríamos de oppida..

Por lo que toca a la construcción de un puerto en la desembocadura del Tiber, en Ostia, es algo más que dudoso, básicamente porque los restos más antiguos de la ciudad de Ostia datan del s.IV, por lo que sencillamente estaríamos ante el control de una especie de población pre o proto-urbana ${ }^{60}$. Respecto a posibles embarcaderos o puentes, dejando la del Sublicio, TAMBORINI ${ }^{61}$ apunta que inicialmente debió existir un sistema de transbordo a modo de barcaza que conectara con la isla Tiberina y que más que un puerto, debió existir un fondeadero natural donde poder atracar los barcos que surcaban el Tíber.

De lo afirmado hasta este momento, resulta bastante difícil concluir que pudiese existir un botín de guerra considerado como res in patrimonio populi, propiamente dicho, pues no hay evidencias materiales que permitan considerar la existencia de una unidad política y, por tanto, de un destino del botín de guerra para satisfacer las necesidades o intereses públicos.

Un último argumento más a favor de nuestra tesis se halla en la preminencia durante esta época de la concepción de la llamada guerra privada (como por ejemplo, el episodio de los Horacios y Curiacios, o posteriormente, el de los Fabios), probablemente de los primeros modos de práctica guerrera, íntimamente relacionada, por contraposición a una concepción de la guerra sometida al control del Estado o a un control público, muy vinculado a un poder central que regulase tal actividad, lo que en Roma puede empezar a evidenciarse a partir de rito de los fetiales, instaurado tradicionalmente por Numa pero llevado a la práctica por Tulio Hostilio, si bien dejan abierta la posibilidad a la adquisición no estatal sino particular del botín de guerra ${ }^{62}$. De hecho, MARTÍNEZ-PINNA ${ }^{63}$, apunta en su estudio sobre los orígenes del ejército romano que incluso en época proto-histórica, el ejército carece de una organización propiamente

59 GJERSTAD, Early IV.1 pág. 45. IV.2, pág. 351-358.

${ }^{60}$ MÁRTÍNEZ-PINNA, Los orígenes de Roma, pág. 163.

61 TAMBORINI, F., La vita económica nella Roma degli ultimi re en Athenaeum 8 (1930), págs. 299-328 en especial pág. 305.

62 TIMPE, D., Das Kriegsmonopol des römischen Staates en Staat und Staatlichkeit, págs. 368-387 en especial pág. 371, 375, 376.

${ }^{63}$ MARTÍNEZ-PINNA, Los orígenes del ejército, págs. 366-367. 
militar, su unidad es la curia, que representa a los guerreros de la aldea, y la gens y la familia dentro de ella.

\section{II.3. La monarquía etrusca}

Durante la monarquía etrusca parece que las cosas empiezan a cambiar, o al menos así lo muestran los testimonios referentes a Tarquino Prisco, Servio Tulio o a Tarquino el Soberbio que ofrece ciertas peculiaridades.

\section{a) Testimonios e interpretación}

Con la monarquía etrusca, parece que el botín de guerra pasa a "ser del rey» y, por ende, con amplias facultades para disponer del mismo, si bien es cierto que no existe una fuente precisa e indubitada al respecto. De hecho, podemos observar como Livio1.37.5-764, al referirse a Tarquino Prisco, afirma que el botín conseguido en la lucha contra los Sabinos, junto con los prisioneros, es llevado a Roma.

Que el botín sea llevado a Roma, puede indicar dos cosas, bien que sea enviado como caudal común del populus o como bienes propios del Rey. Sin embargo, lo que sí que puede suponer, sensu contrario a la práctica habitual realizada anteriormente, es que ya no existía la aparente necesidad de dividirlo en el mismo campo de batalla como parecía que sucedía en épocas anteriores o que, al menos, no existe una necesaria división del botín, lo que supone que la práctica sobre el botín de guerra comienza a cambiar a causa, presumiblemente, de la nueva concepción política que supuso el ascenso al poder de los tarquinos.

De hecho, el rey decide si los vende o si los lleva a Roma ${ }^{65}$, pues es él quien decide del destino de los bienes de la ciudad capturada, como acaece de forma clara con Fidenas a cuyos pobladores les perdona no sólo la vida, sino de la privación de sus bienes ${ }^{66}$.

En todo caso, la satisfacción de los soldados depende en gran medida de la voluntad del rey de entregarles parte del botín como recompensa por los servicios prestados en batalla, pues no hay que ol-

64 «Tarquinius instandum perterritis ratus, praeda captivis que Romam missis»

65 D.H.3.56.4.

66 D.H.3.58.4. 
vidar que el coste de la batalla lo satisfacía cada ciudadano, o para mantener la posición social mediante la riqueza, lo que evidenciaría una sociedad aristocrática ${ }^{67}$.

A esta nueva perspectiva se suma una práctica que comienza a generalizarse: la venta de los prisioneros capturados y, a veces del botín, tal y como se evidencia en DH.3.49.4 quien al hablar de la guerra contra Apiolas y Crustumerio afirma que tras la derrota de los apiolanos, los pocos que quedaron, fueron reducidos a la esclavitud y vendidos con el resto del botín, sus hijos y mujeres hechos esclavos y la ciudad tras ser saqueada fue incendiada. Respecto a Crustumerio, tras su redición, se les permitió conservar sus bienes.

En la toma de Cornículo (DH.3.50 6) dice que los cobardes que consiguieron salvar sus vidas, fueron vendidos como esclavos junto con sus mujeres y con sus hijos.

Si nos preguntásemos quien tenía jurídicamente la potestad de decidir o no la venta de los bienes, es evidente que la respuesta es el rey.

Veamos ahora cuales son las peculiaridades de los testimonios referidos al último rey etrusco. Las diferencias respecto de las anteriores se encuentran en que el rey busca muchas veces el botín para enriquecerse como sucede en Livio 1.57. 1-2 ${ }^{68}$ y donde se dice que la motivación de la guerra contra Árdea, ciudad de los rútulos y pueblo de riqueza pujante, se debió al afán del rey de enriquecerse. Que el rey dispone del botín como le parece al distribuirlo entre los soldados o atendiendo a razones políticas, como sucede cuando reserva parte del dinero del botín de guerra contra los volscos, unos cuarenta talentos de plata ${ }^{69}$, de la toma de Suesa Pomecia a la construcción del Templo de Júpiter en el Capitolino, lo que es confirmado por Dionisio de Halicarnaso ${ }^{70}$, quien dice que reunió toda la plata y oro encontra-

${ }^{67}$ Liv.1.57.4.

${ }^{68}$ ea que ipsa causa belli fuit, quod rex Romanus cum ipse ditari, exhaustus magnificentia publicorum operum, tum praeda delenire popularium animos studebat, 2 praeter aliam superbiam regno infestos etiam, quod se in fabrorum ministeriis ac servili tam diu habitos opere ab rege indignabantur.

69 El hecho de que se hable de dinero o de metales preciosos es indiciativo de una práctica nueva: la venta del botín y de la adquisición de dinero y, por tanto, de economía monetaria, así como la existencia de gastos y de trabajadores empleados en la construcción del templo. Más dudas nos genera Dionisio, pues se refiere a oro y plata directamente, lo que puede tener sentido si aceptamos con DE MARTINO, F., Historia económica de Roma I, Madrid 1983, pág. 68, que los etruscos antes de la acuñación de moneda utilizaban lingotes de plata que pesaban.

70 Liv. 1.53.3; D.H. 4.50.5. 
dos, y tras separar la décima parte para construcción de un templo, distribuyó entre los soldados el resto de las riquezas.

\section{b) Justificación de la interpretación}

De todo lo antedicho, se deprenden una serie de cuestiones que hemos de perfilar para ir viendo si efectivamente podemos hablar o no de patrimonio del pueblo romano o al menos ver cómo van conformándose los elementos que darán lugar a la formación del mismo en época proto-republicana.

La primera surge de la novedad que supone la venta del botín y de la cual se infieren interesantes cuestiones.

La venta de esclavos genera toda una serie de interrogantes jurídicos al respecto y que planteamos a continuación. Si la venta la determina el rey, ¿ en virtud de qué poder y derecho sobre el botín? La pregunta se debe responder a partir de otra cuestión más importante, como es la posible titularidad del botín de guerra.

En nuestra opinión, la razón la podremos hallar en la posible «titularidad» del rey que se infiere de la lectura de los testimonios. Decimos infiere porque ningún texto nos da una noticia que no admita lugar a dudas, pero, por el contrario, de los textos sí que se infiere un cambio radical en el modo de expresarse de los historiadores respecto al modo en que lo hacían en los testimonios anteriores. Así, por ejemplo, se dice que ya Tarquino Prisco ${ }^{71}$, tras derrotar a los tirrenos, «dueño de muchos hombres y riquezas, vendió a los prisioneros y regaló a los soldados lo que quedaba en el campamento». Se videncia, no sólo una clara facultad de disposición, sino también una hipotética titularidad del botín. De forma indirecta, también se deduce de los actos de pillaje que concluyen con el apoderamiento por parte del rey de muchos prisioneros y riquezas ${ }^{72}$ o de la voluntad del monarca expresada del siguiente modo «la hegemonía de las ciudades que poseeré yo».

En todo caso, estos testimonios bien pueden interpretarse en clave retórica y, evidentemente, la fiabilidad de las palabras puede dejar lugar a las dudas acerca de su autenticidad, sin embargo, sean ciertos o no, sean exactos o no los documentos que nos ofrecen los historiadores, una cosa parece ser verosímil: que existe un claro cambio en el

${ }^{71}$ Dionisio de Halicarnaso en 3.53.5.

72 D.H.3.57.5. 
modo de concebir la «titularidad» del botín de guerra y de su disposición; que se corresponde forma clara con un cambio en las formas y poderes con los que se ejerce la monarquía en Roma. Esto debe entenderse en clave política desde la centralización y formalización del poder en la figura del monarca, así como de la guerra y de los recursos obtenidos en la misma.

Visto pues que se procede a la venta, cabría preguntarse por qué es necesario proceder a la misma de forma tan rápida. La cuestión parece un tanto lógica, y creemos que no es necesario recurrir a las fuentes para entender que los prisioneros, entendidos como grupo, resultan peligrosos, por lo que la comunidad política procede con cierta cautela al venderlos a los particulares mediante subasta, como dice Dionisio de Halicarnaso ${ }^{73}$ o comprándoselos a los soldados a quienes previamente el "general» les había permitido adquirirlos. De este modo, se conseguía someter a los esclavos al control concreto de quien los compra, pues de no ser así, habríamos de pensar en una masa ingente de siervos públicos de difícil acomodo en una sociedad nada burocratizada y con pocos servicios públicos que prestar que exijan atención constante.

Una vez aceptada la venta de esclavos y que se separen del botín, ¿implica algún tipo de distinción jurídica por razón de la cosa? Esto es, ¿supone que se distingue entre cosas mancipi y nec mancipi? Esta tesis nos la puede sugerir $\mathrm{EDER}^{74}$, quien afirma que con el incremento del control público durante la época de los Tarquinos el botín se dividiría entre bienes mancipi, no susceptibles de apropiación individual, y los nec mancipi.

Sin embargo, esta tesis no nos convence, por la sencilla razón de que creemos que las fuentes utilizarían la expresión mancipi o nec mancipi, y en caso de no usarla, cabría preguntarse por qué no se refiere a los caballos, animales de tiro y carga cuando habla de separar bienes del botín y sólo se refiere a los esclavos o, sin ser parte del botín, al ager publicus. En nuestra opinión, parece más razonable pensar que la separación no depende de la importancia o naturaleza jurídica que se le quisiese dar a la cosa, sino más bien de cuestiones meramente pragmáticas.

Aceptada pues la venta de esclavos, cabe que nos preguntemos qué se puede deducir 1) de la venta de los esclavos en el mercado y, por otro lado, 2) cuál pudo ser el destino material de tal producto, 3)

73 DH. 4.24.2.

74 EDER, Servitus, pág. 129. 
dónde se ubicaba el tesoro en esta época, a qué gastos se destinaba y quien lo administraba y sobre todo, 4) el fundamento de las facultades para hacerlo.

1) De la noticia de la venta, se concluyen dos ideas capitales que están entrelazadas entre sí. Por un lado, la más que probable participación de Roma en la circuito económico monetario del momento y, por otro, que la obtención de monedas o metales preciosos es el primer paso ${ }^{75}$ para la formación de un «thesaurus»y, con ello, para hablar de una res publica en forma de dinero público ${ }^{76}$. De hecho, la obtención de metales preciosos o de dinero por la venta del botín, destinados al Erario se multiplica, como veremos en el apartado siguiente. Podemos remontarnos pues a los tiempos del rey Servio Tulio $^{77}$ de quien se afirma que bajo su reinado empezó a circular una unidad de medida metálica, la libra de bronce, es decir el as.

Lo antedicho, se debe enmarcar en un contexto económico donde la ampliación y diversificación de recursos y ámbitos económicos contribuyeron a la formación de la $u \mathrm{rbs}^{78}$ ya desde los tiempos del primer Tarquino ${ }^{79}$. Para DE FRANCISICI, la Roma etrusca termina siendo un centro comercial y artístico ${ }^{80}$.

2) Obtenido pues un rendimiento de la venta, ¿cuál pudo ser el destino material de la venta?. Es evidente que parte del botín de guerra debía de ser utilizado para pagar el coste de las infraestructuras y de las obras que dieron lugar a la urbanización de Roma, pues, tal y como vimos en el apartado anterior, se debe a los reyes etruscos des-

75 LATTE, The Origin of the questorship TrPA 67 (1936), 24-33 en especial pág. 31.

76 FERNÁNDEZ, P., El Aerarium Militare en Espacio, Tiempo y Forma, Serie II, Historia Antigua, 16 (2003) págs. 197-214 en especial pág. 201. Según la autora, los tesoros públicos que se guardaban en el Aerarium eran, reproducimos textualmente: 1 . El dinero público y de las cuentas con sus correspondientes recibos, gastos y los deudores.; 2. Los estandartes de las legiones (Liv.,3.69; 4.22; 7,23); 3. Las leyes decretadas y grabadas en las tablas de bronce expuestas (Suet, Vita Caes., 28); 4. Los decretos del Senado, que fueron inscritos allí en depósito, aunque los documentos originales fueron preservados en el templo de Ceres bajo custodia de los ediles (Fla. Josep. 14,.10,10; Plut. Cat. Min. 17; Cic. de Leg.3,4; Tac. Anna3,50). 5. Otros papeles y registros de importancia.

77 DE MARTINO, Historia económica, pág. 68.Los etruscos conocían el mercado monetario, especialmente, dejando circular ya durante el siglo VII a.C. monedas griegas y acuñando monedas de plata y oro en el s.V a.C

${ }_{78}$ BLAZQUEZ, J. M., Historia de roma I. La republica romana, Madrid 1999, págs. 51-52.

79 AMUNÁtEGUI, C. F., Tarquino Prisco en REHJ 31 (2009) págs. 61-85 en especial págs. 67-68.

80 DE FRANCISCI, Primordia, pág. 716. 
de los tiempos de Tarquino Prisco ${ }^{81}$ la urbanización de la ciudad (Roma como ciudad). La influencia etrusca no se produce de forma abrupta, sino que va siendo paulatina ${ }^{82}$, haciéndose más patente a partir de la entrada de la monarquía etrusca. De hecho, ya a partir del siglo VII comienzan a fluir las ideas etruscas en el área de Roma y comienzan a sustituirse las cabañas en verdaderas casas de piedra cubiertas con tégulas, situándonos en época proto-urbana y consolidándose el proceso de densificación de las aldeas, pero es especialmente a partir de la monarquía etrusca cuando se puede constatar arqueológicamente la aparición de grandes cantidades de cerámica etrusca y la realización de obras hidráulicas y otras construcciones en la zona del Foro, dotándose entre el 575-550 de las más importantes estructuras políticas (regia y asamblea popular) y religiosas, así como la obra monumental ${ }^{83}$. Que la urbanización contribuye a la formación de núcleos políticos y culturales, es una noción de la que son conocedores los etruscos ${ }^{84}$, pues como dice OGILVIE ${ }^{85}$, «los etruscos eran, por excelencia, moradores de ciudades», cultura que traen en su equipaje cultural los reyes etruscos ${ }^{86}$. Para DE FRAN$\mathrm{CISCI}^{87}$, cabría añadir un elemento más al meramente cívico y político; cabría añadir el religioso pues, en su opinión, para los etruscos la urbs era considerada como un templum terrestre según la disciplina etrusca

Ello evidencia, no sólo una materialización de las nuevas concepciones políticas, sino que su realización implica encontrar fuentes de financiación, como por ejemplo, el botín de guerra, que contribuiría a una concentración de riqueza para poder invertir en edificios

81 DE FRANCISCI, Primordia Civitatis, Roma 1959, pág. 658. Liv.1.38 Maiore inde animo pacis opera incohata quam quanta mole gesserat bella, ut non quietior populus domi esset quam militiae, fuisset. Nam et muro lapideo, cuius exordium operis Sabino bello turbatum erat, urbem qua nondum munierat cingere parat, et infima urbis loca circa forum aliasque interiectas collibus conualles, quia ex planis locis haud facile euehebant aquas, cloacis fastigio in Tiberim ductis siccat, et aream ad aedem in Capitolio Iovis quam voverat bello Sabino, iam praesagiente animo futuram olim amplitudinem loci, occupat fundamentis.

82 OGILVIE, R. M., Roma antigua y los etruscos, trad. Ana Goldar Early rome and the etruscans, Glasgow 1976, Madrid 1982, pág. 32.

${ }^{83}$ KOLB, La ciudad, 144-145; LARA, F., Los etruscos. Pórtico de la historia de Roma, Madrid 2007, pág. 90.

${ }^{84}$ PALLOTINO, M., Etruscologia, 2 reimp. 7 ed.1984, Milano 1990, págs. 308-309.

85 OGILVIE, Roma, pág. 32.

${ }^{86}$ ROMANO, A., Dal pater gentis ai patres della organizazzione cittadina. Note sul fondamento della leadership arica en Ricerche sulla organizazzione gentilizia romana 1, Napoli 1984, pág. 83-117 en especial 102-103, citando a DH.3.47.2.

87 DE FRANCISCI, Primordia Civitatis, pág. 658. 
públicos. ¿Significa esto que al necesitar de un caudal de dinero o riqueza, esta tuviese que ser necesariamente del pueblo? No, evidentemente, si tenemos en cuenta que las obras, durante el periodo arcaico, lo realizaban los propios habitantes de la ciudad (munera), por tanto, una obligación no retribuida y coactiva que recaía sobre la población para la realización de obra pública.

Precisamente, el hecho de que el botín se utilizase para pagar lo que de otro modo correspondería a la plebe se observa en Liv. 1.57.2 cuando se afirma que el rey obtuvo el botín para aplacar a los plebeyos, hostiles a la monarquía por tales trabajos, llegando incluso al suicidio (Plin, 36.24.107; Serv. Aen. 12.603: D.H.4.44.1-2) ${ }^{88}$.

Ello evidencia que políticamente era necesario utilizar otros recursos para evitar el malestar. Así, MILAZZO ${ }^{89}$ estudia supuestos en los que existe una intervención financiera con probables fines retributivos de los artesanos (Plutarco 13.1 se refiere a los artesanos etruscos y Livio 1.56.1 fabri undique ex Etruria acciti $i^{90}$ ) que, junto con los munera evidencian, según el autor, un régimen mixto con el botín de guerra utilizado para la construcción del templo de Júpiter o los templos de Saturno y de Ceres, Liber y Libera.

El hecho de que se utilice mano de obra plebeya o ciudadana para la construcción y no el producto del botín, permite inferir que tal vez el botín es del monarca y no del pueblo y que el rey dispone de él como le place o considera políticamente

Esta supuesta «titularidad» real se evidencia en el hecho de que todos los testimonios analizados afirman que el rey es dueño o que actúa como tal, cuando toma, por ejemplo, la ciudad de Suesia Pomecia, con afán de lucrarse y obtener riquezas. Es claro en este sentido el testimonio de Cicerón quien diferencia claramente un patrimonio del pueblo de Roma en época republicana ${ }^{91}$. Dice Cicerón ${ }^{92}$ que pudo cumplir la promesa de construir el templo de Júpiter Capitolino gracias a que et maxima auri argentique praeda locupletatus. También Floro ${ }^{93}$, quizá confundiendo praeda con manubiae (parte

${ }^{88}$ MILAZZO, F., La realizazzione delle opere publiche in Roma arcaica e republicana, Napoli 1993, pág. 20. Según este autor y de quien hemos tomado los textos, el Circo, el templo de Júpiter sobre el Campidoglio, Juno y Minerva, la Cloaca Máxima (Liv.1.59.9).

${ }^{89}$ MILAZZO, La realizazzione, pág. 22.

90 DH.4.59.1 se refiere a artesanos.

91 Cic. Verr. II, 1,57 .

${ }_{92}$ Cic. de rep. 2.24.44.

93 Flor.1.2.7. 
del botín que le corresponde al general) dice que de manubiis captarum urbium templum exerit. Sólo Livio ${ }^{94}$ parece que se refiere a pecunia publica a perficendum templum, si bien entra en contradicción cuando dice que una de las causas por las cuales Tarquino planeó la toma de Árdea fue con afán de enriquecerse y porque sus recursos -del rey- estaban agostados por las obras públicas exhaustus magnificentia publicorum operum.

3) ¿Dónde se depositaba el botín?

El lugar en el que se depositaba nos puede dar alguna idea de la supuesta «titularidad del botín». Hemos de partir de un hecho claro, y es que del lugar en el que se depositaba el producto de las ventas del botín, cuando no era distribuido entre los soldados, no hemos hallado testimonio alguno que informe de ello.

Sin embargo, hay un testimonio del que, sensu contrario, se puede inferir el lugar en el que se pudo depositar el botín. El testimonio nos lo aporta Plutarco refiriéndose a Publícola, quien destinó la recaudación de un impuesto, quizá el aes hordiarum, al templo de Saturno para que no estuviese en manos de ningún particular ni amigos suyos.

Esta información es muy valiosa porque nos hace pensar que posiblemente el botín se hallase guardado y custodiado en la Regia ${ }^{95}$, edificio que, en palabras de MARTÍNEZ-PINNA ${ }^{96}$, «representa un perfecto exponente de nueva ideología real, pero que al mismo tiempo pretende integrar en lo posible las antiguas tradiciones», o distribuido en las casas particulares de los auxiliares del monarca.

Que la Regia pudiera ser el lugar, o un lugar, en el que se depositaba botín o el producto del mismo puede tener sentido en la medida en que durante la época proto-republicana, el tesoro pasa al templo de Saturno, deidad vinculada con la riqueza, y que en la Regia, junto a Marte (October equus, festividad relacionada con el ciclo de la guerra, concretamente con el fin de la "temporada de guerra», y vinculado al triunfo del rey ${ }^{97}$ ) existía una capilla destinada a $O p s$, esposa de

${ }^{94}$ Liv.1.56.1.

95 COARELLI, Roma, pág. 79; Il Foro, págs. 61-72 ss. quien considera que la regía no solo tendría un carácter religioso sino que no se puede excluir que, por la disposición de la planta arquitectónica, existiese las dependencias o una de las dependencias reales. GUILLÉN, Urbs III, pág. 254. BAYET, Histoire, pág. 97.

96 MARTÍNEZ-PINNA, Tarquinio Prisco. Ensayo histórico sobre la Roma arcaica, Madrid 1995, pág. 187.

97 DUMEZIL, Rituels indo-europeens a Rome Paris 1954, pág. 78. 
Saturno (Fest. 203.19), con la que se simbolizaba la tierra dadora de bienes al género humano o que representaba incluso la misma Tierra Madre (Varr. 1.1.5.64) y garantizaba mediante el alimento la supervivencia de la comunidad.

Su sacrarium $^{98}$ era el más antiguo que esta divinidad tenía en Roma y su función de proveedora de beneficios para la comunidad se materializó en la Regía en un silo subterráneo excavado en el patio del edificio que se ha identificado con el almacén de la domus real «nella più piccola stanza orientale de la Regia»"

Otro aspecto relevante del culto a Ops relacionado con las atribuciones del monarca fue el carácter privado de su culto durante la monarquía, pues con ello se pretendía reservar al monarca la atribución de ser el único que canalizase la prosperidad y la existencia de la antigua Roma, apareciendo el rey como dispensador de bienes y garante de la prosperidad y existencia de Roma.

El hecho de que se deposite en la Regia, y concretamente en el sacrarium de Ops, se realiza por razones ideológicas y de fundamentación del poder de la nueva dinastía real: el silo de la domus regia estaba en la Regia y que, por tanto, el botín formaría parte de esos bienes que pertenecían, sino al monarca en un sentido jurídicamente estricto, sí al menos como bienes atribuidos a la monarquía en el contexto de sus facultades como garante de la comunidad y dispensador de bienes, quedando depositados en los almacenes de la Regia. ¿Por qué entonces se pasó al templo de Saturno tras la caída de la monarquía y se formó el Erario? Esta es una pregunta que responderemos en el apartado siguiente.

Lo afirmado hasta este momento evidenciaría el importante control del rey sobre el botín de guerra, lo que nos lleva a preguntarnos por el fundamento de dicha facultad y nos lleva necesariamente al siguiente punto:

4) La nueva fundamentación del poder de los reyes etruscos.

Según una nueva e interesante tesis expuesta por autores como MARTÍNEZ-PINNA ${ }^{100}$, ven el poder del monarca fundado en una fusión de elementos latinos-religiosos y etruscos.

98 MARTÍNEZ-PINNA, Tarquinio, pág. 190,191.

99 COARELLI, Il Foro, pág. 62.

100 MARTÍNEZ-PINNA, La monarquía romana arcaica, Barcelona 2009, pág. 30.VAN DER VLIET, E.Ch.L. Early rome and the Early State en Staat und Staatlich- 
El marchamo de poder político etrusco de carácter más formal se aprecia en el imperium del que gozan los reyes del siglo VI a.C. este poder les atribuye la capacidad de mando militar y de gobierno ${ }^{101}$.

Sin embargo, y aquí es donde radica la novedad de estos autores, el imperium es insuficiente para legitimar el poder del monarca etrusco, dado que no alcanzan el poder según la regularidad propia en que lo hicieron los reyes latinos.

Esa falta de legitimidad hace que los reyes busquen en la religión un soporte ideológico que los legitime y que justifique su monarquía. De ahí, la importancia del triunfo y de Júpiter para Tarquino Prisco; la Fortuna y el templo de Diana en Servio Tulio y el Templo de Jupiter Optimus Máximus para el último de los Tarquinios (de ahí la construcción del templo de Júpiter Capitolino -Optimus Máximus- y que el Capitolio pasase a ser el centro político y religiosos de Roma, junto con el cívico Foro, en detrimento del Palatino, referente político y religioso de los reyes latinos $)^{102}$, y que contribuiría a dar continuidad al fundamento del poder de época latino-sabina -eine Symbolwirkung-. La personificación del Dios otorga al rey una posición exclusiva en la sociedad como representante de la sociedad ante el nuevo poder divino.En palabras textuales de MÁRTINEZPINNA «el rey se presenta ante la ciudad como vicario de Júpiter y por tanto garante último de su supervivencia»...«destino que garantiza Júpiter».

En definitiva ${ }^{103}$, un poder absoluto en aquiescencia con los dioses que, en opinión de DE FRANCISCI ${ }^{104}$, «nella fase etrusca, il centro digravità del potere (con le guerre di conquista e con il conseguente or-

keit in der frühen römische Republik, Stuttgart 1990, págs. 233-257, 234, 235, 244, 245. LINKE, Von der verwandschaft, pág. 110. BLÁZQUEZ, Historia, pág. 57.

101 DE MARTINO, F., Storia della costituzione romana 1, pág. 118. Somos conscientes de la cuestión interesantísima que se ha suscitado entre aquellos que han aceptado la existencia de un imperium de origen etrusco o aquellos que, como DE FRANCISCI u ORESTANO, sobre la cuestión del anacronismo que supone utilizar categorías elaboradas durante la república como auctoritas, potestas o imperium, en relación con la expresión que refiere Pomponio en D.1.2.2.1 Et quidem initio civitatis nostrae populus sine lege certa, sine iure certo primum agere instituit omniaque manu a regibus gubernabantur y el carácter antropológico y jurídico de la manus como elemento que evidencia poder en relación con los reyes etruscos

102 LINKE, Von, pág. 125. Respecto a Jupiter Feretrio: pág. 126, 128 lo que supone una nueva dimensión de Jupiter mucho más fuerte, otorgándole el papel principal en la constelación religiosa: es el Dios-rey, el más fuerte y poderoso. MARTíNEZ-PINNA, La monarquía, pág. 33

103 BLAZQUEZ, Historia, pág. 57

104 DE FRANCISCI, Primordia civitatis, pág. 722. 
dinamento territoriale, censitario e militare della popolazione) é stato sopostato verso l'attività militare e che questa è venuta a costituire il carattere più saliente del potere di colui che stava a capo della nueva organizazzione», lo que se evidencia en la ceremonia triunfal (qui Iovis optimi maximi ornatu decoratus curru aurato per urbem vectus in Capitolio ascenderit).

El soberano, pues, no es sólo quien intermedia entre los dioses y los hombres; el que dice que no sólo qué es lo recto sino que además goza de un poder esencialmente irrestricto ${ }^{105}$.

En nuestra opinión, ello se traduce en que sea el monarca quien decida cuál es el mejor destino que se puede dar al botín de guerra: entre ellos un reparto justo entre los soldados, lo que contribuye a mantener la estabilidad del monarca en el poder, o bien satisfacer con ellos el pago de obras públicas, pago que realiza el monarca con sus propios recursos -el botín-.

La última pieza que nos faltaría para completar la evolución del botín como res in patrimonio populi en época proto-republicana es la formación del populus, para lo que traemos a colación la tesis de DEVOTO $^{106}$ quien trata de evidenciar no sólo su origen, que no se corresponde con el de naturaleza propiamente política, sino también el cambio que este término sufrió para adquirir el sentido político que nos es conocido a todos.

Según el lingüista italiano, populus es un término latino derivado de elementos mediterráneos ${ }^{107}$. Según DEVOTO $^{108}$, se trataría pues de un término que formaría parte de las palabras latinas que no encuentran una satisfactoria explicación en el lenguaje indoeuropeo y que podría tener un origen no indoeuropeo, sino mediterráneo (tirrénico $)^{109}$, y que tal vez hubiese influido en el seno de la lengua latina. De hecho, para indoeuropeistas como BENVENISTE, GRAMKRE-

105 DE MARTINO, F., Storia della Costituzione 1, 119.

106 DEVOTO, G., Storia de la lingua di Roma, Modena 1969, reimp. Bologna 1944.

107 LOMBARDI, G., Su alcuni concetti del diritto pubblico romano: civitas, populus, res publica, status rei publica en AG 5ª. (1941), pág. 192-211 en especial pág. 199 quien considera que término populus deriva de una raíz indoeuropea que alude a una multitud armada, siguiendo a MOMMSEN.

108 DEVOTO, pág. 50.

109 DEVOTO, pág. 37, quedaría como el «ambiente» preexiste al que se verían influenciados los grupos indoeuropeos que sobrevivieron a las migraciones y asentamientos en Italia, y que contribuyeron a atenuar los caracteres distintivos entre los diferentes grupos. 
LIDZE e IVANOV, y romanistas como CATALANO ${ }^{110}$, el término con el que se designa a grupo social amplio, político (desconocedores de la ciudad en las grandes migraciones, entre los indoeuropeos "gli uomini facevano lo stato, dovunque si trovassero») $)^{111}$, que une a tribus y clanes es el *theu-te o *teuta (que es un término abstracto primario en *ta y sacado de la raíz teu-, que significa «estar hinchado, ser poderoso» e indicar la plenitud del cuerpo social e identifica sociedad y ciudad. Según DEVOTO, tiene carácter político (asamblea ${ }^{112}$. El hecho de que se designe con nombres distintos para referirse a esas unidades sociales superiores a tribu y al clan se puede deber, según BENVENISTE, a la separación de latinos, helenos o indoiranios antes de que prevaleciese el término "teuta.

En este caso, se refiere a poplo ${ }^{113}$ como un término latino que viene unido o que concuerda con una raíz mediterránea que significa «crecer» (en lengua indoeuropea sería leudh ${ }^{114}$ que daría una noción marginal de pueblo, como aquello que desciende de un origen común) que ha dado vida tanto a términos geográficos como Boplo y a un término de organización social como es «pueblo».

Se presume pues una evolución del sentido de «crecer» al político (en indoeuropeo teuta, en latín populus) que nace de las influencias y contactos entre las lenguas osco-umbras, donde popolo- más cercano al concepto de masa, proto-latinas, entre las que no existían bases hereditarias comunes y numerosas que permitiesen un acercamiento

110 BENVENISTE, Vocabulario, 235; GRAMKRELIDZE, T.-IVANOV, V., Indoeuropean and indo-europeans, Berlin-New York 1995, pág. 653. FORSTON, IV B.W., Indoeuropean. Language and Culture, Oxford 2005, pág. 19. VILLAR, F., El indoeuropeo y los orígenes de Roma, Madrid 1996, pág. 134 dice que en latín «tota» se refiere a «toda Roma», interpretación que nos parece forzada y frente a la que preferimos la de DEVOTO, Origine Indoeuropee, Firenze 1962, pág. 319, para quien este término, recibido en latín, carece de carácter político; CATALANO, P., Populus romanus quirites, Torino 1974, pág. 111. Ver también, CALZADA, A. Origo, incolae, municipes y civitas Romana a la luz de la Lex Irnitana», AHDE, 80 (2010), págs. 673-688; Ibidem RIDROM 4-2010, 1970. págs. 17-51.

111 DEVOTO, Gli antichi italichi, 3 ed. Firenze 1967, págs. 223-224.

112 DEVOTO, Origine, pág. 319. Es conocido en el céltico, el báltico, el germánico y el itálico, pero desconocido para el latín o el griego, además del eslavo, del armenio y del indoiranio.

113 DEVOTO, Origine, pág. 319., DEVOTO, La língua, págs. 53, 62-63, 77-79.

114 BENVENISTE, Vocabulario, págs. 209-210. Leudh-indica crecer, desarrollarse $\mathrm{y}$, aunque de este término también se deduce un término que indica pueblo y gentes, que se relaciona, no con populus sino con liber, para referirse a los niños y al dios Liber, designándose a aquellos que proceden de un tronco étnico designado por una metáfora del crecimiento vegetal, lo que le confiere un privilegio que ni el esclavo ni el extranjero conocen. 
entre ambas lenguas, quedando sometidas en determinados períodos de tiempo a la lengua etrusca: A esta fase se denomina "fase itálica». Según el filólogo italiano, de Etruria ${ }^{115}$ provienen, de la época de los Tarquinos, los elementos lexicales vinculados al modo específico de organización estatal introducidos por una clase dominante que organiza el Estado según criterios nuevos y distintos a los anteriores y entre los que se incluye el término latino populus que vendría a representar a la gente organizada en un embrión de Estado.

Junto con el término populus se encuentra el adjetivo par con el que se significa la condición de iguales entre los miembros de una comunidad política y que tienen sus correspondientes etruscos en pupli y en el derivado parchis. Según LARA ${ }^{116}$, el conjunto de todas las gentes (metlum) que se subdividía en clases según su riqueza formaban el pueblo etrusco de personas libres, todas en pie de igualdad determinados por su montante económico (posesión de tierras, comercio, mercaderías, artesanía) pero con diferentes responsabilidades en la paz y en la guerra, Todas aquellas gentes reconocían la figura de un jefe en quien se habrían depositado el poder político y religioso

De lo afirmado por DEVOTO y LARA se deduce que pensar en un populus, entendido como organización de una comunidad políticamente de iguales (ciudadanos), o al menos un populus designado con esta palabra hay que situarla como mínimo en la época de los Tarquinos (habría que ver que Tarquino) siendo clara la influencia etrusca, lo que dará pie a poder a hablar de civitas $^{117}$.

En particular, creemos que los momentos más importantes a tener en cuenta, sin olvidar la importancia que supuso la figura de Tarquino el Antiguo para legitimar y cimentar, son los periodos de los reyes Servio Tulio, y Tarquino el Soberbio, pues con la política de fusión de lo latino con lo etrusco ${ }^{118}$ y las reformas políticas del primero parece que podemos empezar a hablar de populus ${ }^{119}$ como superación del concepto basado en la suma de los miembros de los grupos gentilicios y pasar a una integración de las diferentes partes de población en un nuevo orden social que permitiese la creación de una nueva sociedad, lo que nos lleva a pensar ya en la comunidad política romana

115 PALLOTINO, Etruscologia, pág. 307.

116 LARA, F., Los etruscos. Pórtico de la historia de Roma, Madrid 2007, pág. 154.

117 DE MARTINO, Intorno al origine de la repubblica romana e delle magistrature en Diritto economía i società nel mondo romano 2, Napoli 1995-1997, págs. 157189 en especial 158

118 OGILVIE, pág. 69.

119 LINKE, Von der Verwandtschaft, pág. 124. DE MARTINO, Intorno, pág. 218. 
como posible sujeto de derecho. Por su parte, con Tarquino el Soberbio podremos ver la evolución del urbanismo de la ciudad de Roma y a la que se destina parte del botín guerra como consecuencia, según OGILVIE ${ }^{120}$, y por analogía con las tiranías griegas, como una política tendente a justificar su posición mediante grandes construcciones y aventuras internacionales ambiciosas.

Se dan pues históricamente una serie de variables que hemos de tener en cuenta a la hora de poder hablar de las res in patrimonio populi romani o cuanto menos, tomarlas como punto de partida en contexto de una futura aparición y evolución de esta institución jurídico-pública, en tanto que se trata de dos variables claves en materia de res in patrimonio populi, a saber, el posible titular del derecho y el destino de los bienes. Ello se aprecia mucho mejor si aceptamos con BONA $^{121}$ que el botín de guerra permanece in patrimonio populi durante la república, lo que pondría de manifiesto los primeros cambios para aceptar esta tesis.

\section{II.4. La época proto-republicana}

Analizada la época monárquica, queda centrarnos en la época proto-republicana donde se puede empezar a hablar del botín como una res in patrimonio populi y para ello nos centraremos en la figura de Publícola, pues es según Plutarco, a quien le debemos la formación del Erario (Aerarium de aes ${ }^{122}$ ) en el Templo de Saturno ${ }^{123}$ y, por ende, poder hablar de caja pública o de tesoro público ${ }^{124}$. Macrobio es explícito en este sentido cuando dice que 1.8.3 Ideo apud eum locaretur populi pecunia communis, sub quo fuissent cunctis universa com-

120 OGILVIE, pág. 70.

121 BONA, preda, pág. 911.

122 STELLA-MARANCA, F., voz a erarium, en NNDI, 1.2 (1957), págs. 340-341; ETXEBARRRIA, A., Los foros romanosrepublicanos en la Italia centro-meridional tirrena. Origen y evolución formal, Madrid 2008, pág. 222.

123 CORBIER, M., Aerarium Saturni et l'Aerarium militare.Administration et prosopographie sénatoriales. Rome, 1974, pág. 632.

${ }^{124}$ LONGO, A., Carattere giuridico dell amministrazione finanziaria romana en AG 47 (1891), pág. 110-148 en especial pág. 114, El Templo de Saturno como Erario, en opinión de LONGO, debe considerarse como «caja pública» y no confundirse con patrimonio, es decir, que el patrimonio no es el erario sino lo que se haya dentro de él, como por ejemplo, lo sería el resultado de la venta del botín. Era el «Stabulum aerarii», (tesoro-casa) la Hacienda o Caja pública de Roma, (de "Aes» latino, en su sentido derivado del «dinero»), propiedad del Senado y el pueblo romano, cuya superintendencia y administración dependía del propio Senado. 
munia. Lo mismo que A. Victor 3.6 en de origine gentis romanae cuando dice que Aedes quoque sub Clivo Capitolino, en qua pecuniam conditam habebat, aerarium Saturni hodieque dicitur.

En primer lugar vemos que, en tiempos de Publícola (Plut. 22.3), la victoria sobre los sabinos en el 504 supuso fortalecer al pueblo romano con recursos y prisioneros. A este fragmento hemos de añadir como Publícola (12.3), en materia de impuestos y para evitar suspicacias que lo vinculasen al régimen anterior, permitió al pueblo nombrar cuestores -quaestores ${ }^{125}$ - y depositar la recaudación en el templo de Saturno, con el fin de evitar que amigos suyos dispusiesen de los recursos y que estos se depositasen en casas particulares.

Ambas noticias son de sumo interés, la primera porque se habla de fortalecer al pueblo romano con recursos producto del botín y la segunda porque, aunque se refiera a los impuestos, evidencia que la decisión de depositar la tributación en el Templo de Saturno y sacarla de la Regia, responde a motivaciones políticas ${ }^{126}$. Con ello evitaba cualquier tipo de suspicacia al depositar el dinero en lugar público, concretamente en los sótanos del templo de Saturno. El control de esos bienes queda en manos de cargos elegidos por el pueblo (questores -Publio Veturio y Minucio Marco-), encargados de la administración mientras que el senado tendría derecho de disposición ${ }^{127}$. Todo ello nos sitúa al menos a inicios de la República; a finales del siglo VI a.C.

Nos preguntamos pues ¿por qué se escogió el templo de Saturno como lugar en el que depositar el botín?. Una primera repuesta la ofrece el propio Plutarco quien nos ofrece dos opciones: Afirma en Cuestiones Romanas 42 (275A) que el Erario se ubicó en el Templo de Saturno por razones de seguridad al ser un lugar bien protegido, abierto y difícil de atacar en secreto o por razones de índole mitológica y religiosa (bien por recordar el mítico gobierno de Saturno donde reinaba la paz, la justicia y la riqueza, bien por ser el Dios que protege las cosechas y la agricultura, protector de la abundancia y la

125 D.1.2.22; (Ascon). Verr, 2.1.11 según SOLINAS, G., Alcune regflessione sulla figura del tribunus aerarius en Atti del II Seminario Romanistico Gardesano (1980), pág. 313-332 en especial 322 nt.12. Lex Iul. Munic. 39 s q(uaestor) urb (anus) queive aerario praerit. Traido de ORESTANO, Il problema, pág. 211 nt.62.

126 DE FRANCISCI, Dal «regnum», pág. 161.

127 KUBITSCHEK, Aerarium en PW, 1.2 (1893),p.667-674 en especial págs. 669670. Al respecto Polib. Hist. 23.14.5 y ss, como, en tiempos de Escipión el Africano, la administración corresponde al cuestor, pero la rendición de cuentas de los gastos producto de las campañas son realizadas ante el senado. 
prosperidad, pues de la abundancia de los frutos y de su venta nace la abundancia de dinero).

También Macrobio apunta esta última razón como causa de que se depositase en el templo cuando dice que 1.8.3 aedem vero Saturni aerarium Romani esse voluerunt, quod tempore quo incoluit Italiam fertur nullum in eius finibus furtum esse commissum aut quia sub illo nihil erat cuiusquam privatum: nec signare solum aut partiri limite campum / fas erat: in medium quaerebant... /

Dichas respuestas son válidas, pero creemos que hemos de ir un poco más allá. En primer lugar, hemos de pensar en las razones políticas que hicieron que se sacase de la Regia, en particular hay que pensar que con el advenimiento de la República se produce la «ruptura» del centro político-religioso que era la Regia, quedando como centro cultural ${ }^{128}$ administrado por el rex sacrorum, el pontífice máximo y las vestales. COARELLI ${ }^{129}$ habla de una total reestructuración del edificio en zonas parcialmente diferenciadas a finales del siglo VI a.C, dividida en una serie de espacios distintos: Regia en sentido estricto, Templo de Vesta, atrium Vestae, domus regis sacrorum.

Por tanto, hay que ver que el ascenso de la República supuso la desestructuración del centro político y cultual de la realeza etrusca.

En segundo lugar, hay que tener en cuenta el elemento religioso que, en nuestra opinión, se puede sacar alguna conclusión interesante.

Dicho templo era, en tiempos de Tulio Hostilio ${ }^{130}$ un santuario sin templo -the earliest sanctuary describe it as an open cult place with an altar as a sacred center (Dionysios) and called fanum (Macrobius) ${ }^{131}$, , cuya construcción debemos a Tarquino Prisco o el Soberbio $^{132}$ y su dedicación a T. Larcio (Macrobio 1.8.1) o durante el consulado de A. Sempronio y M. Minucio (Liv.2.21.1). El Ara Saturni-in

128 COARELLI, Il Foro, pág. 64.

129 COARELLI, Il Foro, págs. 64-65.

130 Acrob.1.7.37.

131 GJERSTADT, The Temple,p.758; Early Rome, pág. 380. DUMEZIL, G., La religion romaine archaïche, Paris 1966, págs. 431-432. BAYET, J., Histoire politique et psycologhique de la religion romaine, Paris 1969, pág. 26, 176. Estaba asociado posteriormente a un pequeño santuario -sacellum: Festo pág. 422L. Sacella est locus - de Ditis Pater (Plutón, el dios que gobierna las riquezas del mundo subterráneo) et Proserpinae y, por tanto, del culto subterráneo celebrado en altares subterráneos.

132 GJERSTAD, The temple of Saturn in Rome en Hommage A. Grenier, Bruxelles 1962, pág. 757-762 en especial pág. 762 se inclina por el primero, MARCOS, M., Lua 
imo clivo Capitolino- ${ }^{133}$, estaba curiosamente situada cerca del Senaculum $^{134}$, y era considerado como uno de los más antiguos santuarios de Roma, junto con el ara Maxima de Hercules ${ }^{135}$.

A nuestro modo de ver, la razón de que se ubicase en el Templo de Saturno hay que buscarla, no sólo en la política, sino también en el hecho de que existe un factor religioso, dado el parentesco existente entre Ops y Saturno y, con ello, los bienes del pueblo adquieren una cierta dimensión religiosa como bienes necesarios para la subsistencia del pueblo colocándolos bajo la protección de un dios que, precisamente, representa la abundancia, la paz, etc. El hecho de que se deposite en los sótanos del templo, se justifica por ser una deidad tectónica conectada con mundus ${ }^{136}$. Este mundus aparecería desde tiempos antiguos como un silo comunitario en el que se depositaban las primeras semillas y espigas simbolizando con ello la acumulación de provisiones. Estaba ubicado en el centro del espacio urbano, por tanto, en el lugar más protegido: en definitiva, el tesoro de la comunidad $^{137}$.

Se entiende pues que de la Regia, y por tanto de Ops, se pasase al templo de Saturno, dado que son deidades vinculadas y asociadas a la riqueza y a la prosperidad del pueblo; riqueza y prosperidad que depende, entre otras cosas, de los recursos obtenidos como botín de guerra y porque en las Opalia, Ops se desplazaba de su lugar originario en el Foro al Ara Saturni.

Ello supone pues la confirmación de que se ha formado la conciencia de que hay bienes considerados como patrimonio del pueblo, y no de la monarquía u otras instituciones, destinados a satisfacer obras, gastos o empresas comunes a los que deben contribuir el pueblo mediante impuestos o que pueden ser sufragados mediante el dinero o metales valiosos procedentes del botín o de su venta. Pero lo que es más importante: que el carácter sacro del lugar en el que se depositaban evidencia el valor de tales bienes tienen como recursos del pueblo como tal y de los cuales depende su existencia. Este, por tanto, sería un lazo naturaleza religiosa que se mantendría con la

Saturni en Helmantica 31 (1980), págs. 207-231 en especial pág. 219, por el segundo, así como DH.6.1.4.

133 Fest. 430L.

134 Macrob. 1.7.37.

135 CORAELLI, F., Il Foro Romano 1, Roma 1983, pág. 206.

136 COARELLI, Il Foro romano, págs. 210.,224, a modo de silo simbólico de carácter sacro. WARDE-FOWLER, M.A.D., Mundus patet en JRS 2 (1912), págs. 25-33.

137 COARELLI, Foro, pág. 224. 
monarquía etrusca y no se rompería con el advenimiento de la República.

Podemos pues empezar a hablar en materia de botín de guerra, sino de una canónica formación dogmático-jurídica del concepto, sí de la conciencia de que se trata de algo que pertenece a la comunidad en cuanto tal (populus) y del cual depende la existencia de la propia comunidad.

La importancia del Erario en este punto es evidente, pues indica la clara materialización de la existencia de una res in patrimonio populi en la que se contiene el producto de las guerras, especialmente las ventas del botín convertido en dinero público, pues nada hay más básico que, existiendo un concepto de comunidad y de bienes comunes, éstos tengan un lugar concreto en que quedan depositados.

A partir de estos textos referidos principalmente a Publícola, las noticias que nos informan de que el botín se destina al pueblo se multiplican durante la época proto-republicana, así vemos como Dionisio de Halicarnaso afirma que la venta del botín (503 a.C.) ${ }^{138}$ sirvió para compensar la contribución ciudadana a la guerra; en el $485^{139}$, la venta del botín de los Volscos y Ecuos llevada a cabo por Q. Fabio se destinó Roma; la guerra contra los Ecuos llevada a cabo por Sp. Furio, supuso un enriquecimiento del pueblo; en la guerra contra los Volscos llevada a cabo por T. Numicio (469) ${ }^{140}$, se afirma que, después de dejar los esclavos, bienes y mercancías a los soldados, los libres fueron vendidos en subasta. En este caso, es lógico pensar que el montante sirvió para engrosar las arcas públicas; L. Lucrecio en la guerra contra Volscos y Ecuos (462) ${ }^{141}$, afirma que vendió el botín; muy interesante es el testimonio que nos informa de que L. Cornelio en la toma de Ancio, (459) 142 $^{14}$ envió al tesoro el oro, la plata y el cobre; los esclavos y despojos fueron vendidos, y, en nuestra opinión, debió de servir también para incrementar el tesoro, como afirma Livio en 3.31.4 (Eam propter inopiam aerarii consules uendiderunt) en este caso para cubrir la falta de recursos del Erario; Cincinato, en la toma de Corbio (458) ${ }^{143}$, envió lo más valioso a Roma; la venta en subasta del botín por los dictadores Postumio (431) y. Emilio (426) ${ }^{144}$ o la ven-

\footnotetext{
138 DH. 5.47.1.

139 DH. 8.82.4.

140 DH.9.56.5.

141 Liv.3.10.1.

142 DH.10.21.6.

143 DH. 10.25.1.

144 Liv. 4.29.4; 4.34.4.
} 
ta en beneficio del tesoro realizada por Camilo (396) $)^{145}$ tras la toma de Veyes.

De estos textos se deducen toda una serie de conclusiones interesantes como es el hecho de que a Roma llegan como botín esencialmente $^{146}$ el producto de la venta -dinero público- y los metales preciosos destinados al Erario, y por tanto, entendemos como res in patrimonio populi destinado a sufragar los gastos de la civitas, principalmente la guerra que debió ser la principal fuente de gasto. De hecho, vemos que si los recursos públicos escasean son los propios ciudadanos los que la sufragan, siendo reembolsados posteriormente con el propio botín. Sin embargo, es el Erario el que sufraga principalmente esta actividad pues obsérvese que se procura de forma constante mantener las arcas suficientemente provistas de recursos.

Con todo, también se puede observar en otros textos cómo el general, sea cónsul o sea dictador, tiene facultades para disponer del botín, permitiendo el saqueo o el reparto del botín entre los soldados (DH.6.29.4-5; Liv.2.2.5.2; DH. 6.91.3; DH.8.57.1; DH.9.35.3; Liv.2.60.2; DH.9.56.5, etc.) o bien restituyéndolo a los antiguos dueños (Liv.3.10.1).

Esta capacidad que tiene el general, cónsul o dictador, muestra lo que refiere ROBLEDA ${ }^{147}$ al decir que evidencia su capacidad de disposición como órgano público en un acto de asignación -assignatioregido no por derecho privado, sino por derecho público y con el que surge el dominio a favor de algunos (soldados) acto realizado por el órgano público correspondiente -ens publicum- para el bien de la comunidad y por el que la cosa deja de ser del pueblo para pasar a ser de otro.

\section{CONCLUSIÓN}

Queda, para finalizar, apuntar unas breves conclusiones. A lo largo del presente trabajo hemos querido demostrar que la afirmada titularidad del botín de guerra como res in patrimonio populi se evidenció en época republicana, en particular a inicios de la República con Publícola a causa de una decisión política quien destinará esos

145 Liv. 5.21.14; 5.22.1; Plut. Cam. 7.7.

146 Decimos esencialmente porque no siempre, si bien es el único texto, la venta del botín se distribuye entre los soldados (Liv. 5.16.7)

147 ROBLEDA, O., Sobre la capacidad jurídica del populus romanus en St. Grosso 3 (Torino) pág. 103-113 en especial pág. 112. LONGO, A., Carattere, pág. 111. 
bienes a satisfacer las necesidades comunes del pueblo romano, especialmente los gastos derivados de las guerras, evitando con ello que los particulares soportasen las cargas derivadas de la misma.

Sin embargo, es a lo largo de la época monárquica, especialmente etrusca, cuando se van formando los elementos sobre los que se materializará la concepción dogmático jurídica del botín como patrimonio del populus romanus. Así, vemos que durante la monarquía etrusca se conforma políticamente el populus como sociedad política, lo que se manifiesta en las grandes construcciones civiles y religiosas, así como la venta del botín y el pago de las obras o parte de las mismas con el propio botín.

Sin embargo, creemos que sigue siendo un bien cuya titularidad pertenece al rey, o quizás ala monarquía, el cual dispone del mismo como cree oportuno, bien permitiendo el reparto entre los soldados, bien contribuyendo a los gastos de las obras públicas y evitar con ello el enojo de quienes debían de soportarlos.

Así mismo, creemos que puede existir una relación entre el lugar en el que se deposita, tanto en época proto-republicana -el templo de Saturno- y monárquica -la Regia, en el sacrarium de Ops-, con ciertas connotaciones religiosas relacionadas con la abundancia y la riqueza nacional. 